\title{
Dynamic Effects of the "New Age" Free Trade Agreement between Japan and Singapore
}

\author{
Thomas W. Hertel, Terrie Walmsley, and Ken Itakura \\ Center for Global Trade Analysis, Purdue University
}

\begin{abstract}
As manufacturing tariffs have fallen worldwide, the focus of free trade agreements has shifted towards other issues, including: rules governing foreign investment, e-commerce regulations, trade in services, harmonization of technical standards, sanitary and phyto-sanitary regulations, and the streamlining of customs procedures. Japan and Singapore are undertaking negotiations over this kind of "new-age" FTA. The purpose of this paper is to evaluate the impact of the FTA on production, consumption, trade, international investment flows, GDP and welfare. We use a modified version of the dynamic GTAP model, which is well-suited to capturing the impact of this new-age FTA over both the short run and the longer run.

In addition to the proposed bilateral tariff cuts, our analysis takes account of the potential gains from implementing uniform standards for e-commerce in Japan and Singapore. The consequences of liberalizing rules governing direct trade in services are also considered. Finally, we seek to quantify the impact of automating customs procedures in Japan, making them compatible with the computer-based standards established by Singapore. This is projected to reduce the administrative costs and lag time in Japan's exports to, and imports from, all destinations, thereby permitting products to be delivered in a more timely fashion.

We find that the impacts of this new-age FTA on bilateral trade and investment flows are significant - with customs automization playing the most important role in driving increases in merchandise trade. The FTA also boosts rates of return in the two economies, thereby increasing both foreign and domestic investment as well as GDP. This causes the trade balance in both Japan and Singapore to deteriorate relative to baseline over the medium run, although it improves in the long run due to higher foreign income payments. The estimated global gains from this FTA are in excess of \$US 9 billion annually, with the bulk of these gains accruing to Japanwhich undertakes most of the reforms. Unlike preferential tariff cuts, the "new age" components of this FTA promote imports from all sources, thereby eliminating the problem of trade diversion.
\end{abstract}

\section{JEL Classifications: F13}

Key Words: Free Trade Agreement, Dynamics, General Equilibrium, Foreign Investment, Japan, Singapore.

*Corresponding address:Thomas. W. Hertel, Professor and Director, Walmsley is Faculty Associate and Itakura is Research Assistant with the Center for Global Trade Analysis, Purdue University, West Lafayette, IN 47907-1145. Email: hertel@agecon.purdue.edu., website: www.gtap.org Walmsley is also a lecturer with the University of Sheffield, Sheffield, UK. 


\section{Introduction and Overview}

In the past decade, there has been a flood of regional trade agreements. Today, more than 130 such agreements are in place (WTO, 2000). The European Union, the North America Free Trade Agreement (NAFTA) and MERCOSUR have been particularly effective at promoting intra-regional trade. This has led other countries to explore options for such regional agreements, and in December, 1999, Japan and Singapore established a Joint Study Group to examine the feasibility and desirability of establishing a FTA. After a favorable report from the Study Group, negotiations on this FTA commenced in early 2001 (Joint Study Group, 2000a).

The main elements of the prospective Japan-Singapore FTA involve bilateral liberalization and facilitation of trade through reduction of tariff and non-tariff barriers as well as the mutual recognition of national standards, streamlining customs procedures, facilitation of increased services trade, as well as establishment of an exemplary framework for foreign investment. This "new age" FTA also envisions increased collaboration on intellectual property, education and training, media and broadcasting and tourism. This trade agreement is particularly significant, since it is viewed by many as providing a possible template for future FTAs in the region. In particular, another working group has been established to explore the potential for a free trade agreement between Japan and Korea (KIEP, 2000). This is expected to have many of the same "new age" elements.

Japan already trades quite intensively with Singapore and Korea. Based on the Brown-KojimaDrysdale export intensity index, Japan exported about twice as much to these countries as one would expect, solely on the basis of their world import shares in 1998. However, there is some indication that the relative attraction of trading with Korea and Singapore has been diminishing. Figure 1.1 reports Japan's total merchandise trade export bias to Korea, Singapore and Rest of World. Drysdale (1982) uses this measure to capture the determinants of export shares, once the size, openness and product composition of the importing market have been taken into account. Anderson and Norheim (1983) argue that this bias component offers a proxy for the kind of transactions costs that FTAs are 
intended to lower. The higher this bias, the more attractive the export destination, relative to alternative markets.

As can be seen from Figure 1.1, the relative attractiveness of exporting from Japan to Korea and Singapore has been cut in half over the past 30 years. Figure 1.2 reports the export bias from Korea and Singapore to Japan. These, too, have been falling. Thus, while trading costs between Japan and these partners may have fallen significantly over the past 30 years, there is some evidence that trading costs with other partners have fallen more rapidly. In light of this observation, it is perhaps not surprising that these three countries have initiated discussions aimed at lowering trading costs among their respective economies. The goal of this paper is to provide a quantitative assessment of the dynamic effects of one of these "new age" FTAs - namely that between Japan and Singapore.

The paper is organized as follows. In the next section, we outline the key elements of the JapanSingapore FTA and discuss our approach to quantifying them. Given the relatively low level of industrial tariffs on most trade between these two countries, we devote considerable effort to quantifying the non-tariff elements of this agreement. In Section 3, we outline the dynamic modeling approach taken in this paper. It is aimed explicitly at capturing the impact of these "new age" FTAs, not only on trade, but also on international investment flows. In order to analyze the potential impact of these FTAs, it is important to have a view of the evolution of regional trade and growth in the absence of the agreements. This baseline is established in Section 4 of the paper. Section 5 reports the results and analysis based on a comparison of the baseline with the counterfactual, FTA simulations, and this is followed by the conclusions.

\section{Quantifying the New Age Agreement}

\section{Trade and Tariffs}

As with other such regional trade agreements, the FTA between Japan and Singapore envisions bilateral elimination of tariffs (Joint Study Group, 2000a, 2000b). Table 1 reports estimated average 
bilateral tariffs levied by Singapore and Japan on one another's exports. The tariff estimates for Singapore are based on applied rates for 1999, as reported in the WTO Singapore Trade Policy Review (2000). Applied tariffs in Singapore are now zero for all goods outside of alcoholic beverages (other food products in Table 1). This reflects some liberalization from the 1995 applied rates in the version 4, GTAP data base, and these tariff cuts in Singapore are implemented as part of the baseline described in Section 4 below. Based on the non-agricultural tariffs in Table 1, implementation of the FTA will have no direct impact on Singapore's imports of merchandise commodities from Japan hence the calls for a "new age" FTA.

The tariff estimates for Japan in Table 1 reflect the lower of 1995 applied rates, as obtained from the GTAP version 4 database, and WTO bindings under the Uruguay Round. In cases where the bindings are below 1995 tariffs, we reduce them to the level of the post-UR bindings as part of the baseline experiment. Note from the trade share entries in Table 1 that Japan does not import any grains from Singapore. Bilateral imports of meats and other food products are modest, but face a very high average tariff. It is clear from this table why food and agriculture represent a very sensitive part of this agreement. Given the very high tariffs facing these products imported from other destinations, the incentive for trans-shipment through Singapore is likely to be substantial under an FTA. This raises the prospect of significant enforcement costs associated with the rules of origin for this FTA. For this reason, it is quite likely that agriculture will be left out of the final FTA agreement - or perhaps it will be implemented in a delayed fashion. Of course, textiles and apparel products and leather goods also face non-negligible tariffs so that substantial expansion of imports from Singapore is expected under the FTA.

In our study we assume that implementation of the FTA is undertaken in 2005. At the time this work was undertaken, it was unclear how fast Japan and Singapore would move on this agreement. By placing it after completion of the Uruguay Round we also simplified our experimental design. For this reason, we focus on the projected, 2005 trade shares in Table 1 in evaluating the potential impact 
of this FTA (see Section 4 for details behind the baseline projections). Based on the figures in Table 1, it is clear that this trade relationship is highly concentrated, with the bulk of Japanese exports to Singapore involving machinery and equipment. This is followed in importance by business and financial services, petroleum/chemical and mineral products, extractive products and other manufactures. Singapore's exports to Japan are concentrated in the services sector, followed by machinery and equipment and petroleum/chemical and mineral products. Clearly this trading relationship involves a great deal of intra-industry trade that should receive a substantial boost from any reduction in non-tariff trade costs.

\section{Customs Automization}

This brings us to a second aspect of the Japan-Singapore FTA that lends itself to quantification, namely the reduction of customs costs for bilateral trade between these two partners. In building the case for efforts to streamline customs procedures, the Joint Study Group (2000b) cites UNCTAD research indicating that customs paperwork and procedures costs add up to about $7 \%$ of the global value of trade. This is likely a considerable overstatement of these costs in the case of JapanSingapore trade. Nevertheless in an era of increasing regional integration and vertical specialization in production, small trade costs can have a significant impact on intra-industry trade. Furthermore, any costs above $1-2 \%$ will represent a more substantial barrier to trade than industrial tariffs. The Joint Study Group (2000b) has focused on a proposal to reduce customs clearance costs by implementing an Electronic Trade Document Exchange System (ETDS) that will increase the speed of customs clearance, reduce the cost of dispatching information and documents and ensure security of associated documents. Singapore currently has such a system in place, so the emphasis is on extending this technology to Japan's customs procedures.

At the heart of the ETDS proposal resides commercially operated electronic document exchange servers that will facilitate the exchange of customs documents between importers, exporters and the Japanese customs authorities. Introduction of an electronically harmonized custom system will reduce 
the time and cost spent on custom paperwork, processing and shipments. Customs automization will also improve efficiency in shipments of products by eliminating the time spent waiting for custom clearance at ports.

Our estimates of the savings in time and direct costs due to customs automization are based on research conducted in conjunction with the Ministry of Economy, Trade and Industry (METI) and Mitsubishi Research Institute (MRI) in Japan. Through a careful study of the direct costs associated with current customs procedures, as well as the costs of connecting to the ETDS system, the MRI estimates that introduction of custom's automization in Japan would lower the effective merchandise prices for all trading partners by $0.201 \%$ for exports and by $0.203 \%$ for imports. Additional reductions in direct costs arise when a trading partner of Japan also implements the electronic custom system to synchronize the custom clearance. For the case of the Japan-Singapore FTA, the effect of linking the two systems is expected to generate additional reductions in effective prices amounting to $0.065 \%$ in Japanese imports from Singapore and $0.013 \%$ in Singaporean imports from Japan. It should be noted that these cost saving refer solely to the cost of reduced paperwork, storage and transit expenses.

However, in addition to the direct cost savings of ETDS, there are indirect savings associated with the elimination of customs-related delays in merchandise flows between these two countries. Hummels (2000) emphasizes that such time savings can have a profound effect on international trade by reducing both "spoilage" and inventory holding costs. He argues that spoilage can occur for many types of reasons. The most obvious might be agricultural and horticultural products that physically deteriorate with the passage of time. However, products with information content (newspapers), as well as highly seasonable (fashion) goods may also experience spoilage. Hummels points out that inventory costs include not only the capital costs of the goods while they are in transit, but also the need to hold larger inventories to accommodate variation in arrival time. The latter has become increasingly important due to the use of "just in time" production techniques. 
In order to estimate the value of time savings in international trade, Hummels utilizes a detailed data set which he has assembled that includes information on modal choice (air vs. sea), modal prices (shipping rates), and modal shipping times at the 10-digit, HS level for US imports. This results in approximately one million observations per year over the entire 1974-98 period. Hummels (2000) estimates a discrete choice model, wherein the probability of choosing air over sea transport depends on relative freight rates and the associated time savings. He finds that the average value of firms' willingness to pay for one day saved in trade is estimated to be $0.5 \%$ ad valorem (i.e., one-half percent of the value of the good itself). However, this value of time savings varies widely by product category, with the low values for bulk commodities and the highest values for intermediate goods. The first column of Table 2 below (value of one day saved) reports the percentage ad valorem value of a day saved in trade at the level of commodity aggregation used in the present study. The smallest value is $0.13 \%$ /day for leather, while the value of a one day reduction in transit reaches nearly one percent $(0.94 \%)$ per day for petrochemical and mineral products. This value is also quite high for machinery and equipment $(0.51 \% /$ day $)$. Hummels' estimates for agricultural products are not significantly different from zero and are therefore omitted.

The MRI estimates that the amount of time that would be saved by the custom automization would be 1.7 days for exports and 1.5 days for imports. These translate into effective price reductions of $0.85 \%$ and $0.75 \%$ respectively, based on the average valuation of $0.5 \%$ ad valorem per day. Additional time savings are likely if the countries at both ends of the transaction (this is the case with Japan and Singapore) adopt the same EDTS system. The further saving on lead-time is estimated to be an additional 1.3 days for exports and 2 days for imports, or $0.65 \%$ and $1 \%$ reductions in the average effective prices of exports and imports, respectively. By applying these time savings associated with ETDS to Hummels' estimates of the value of time savings, by commodity, we obtain the price reductions associated with customs automization shown in columns (a) to (d) in Table 2. The estimated price reductions in Table 2 vary depending on whether or not the linking effect is 
present. Columns (a) and (b) apply to trade between Japan and ROW, whereas columns (c) and (d) apply to trade between Japan and Singapore. The full set of bilateral shocks associated with customs automization are summarized in Table 3. Note from this table that Singapore's trade with ROW is unaffected by the implementation of ETDS in Japan.

\section{E-Commerce}

Another important element of the proposed FTA is the section aimed at improving security and harmonizing standards governing B-to-B and B-to-C e-commerce between Japan and Singapore. The goal of this part of the agreement is to make e-commerce between the two countries as safe and acceptable to customers as is domestic e-commerce presently. Accordingly, we have taken estimates of the extent of B-to-B e-commerce penetration in the domestic Japanese market (column one of Table 4), along with the MRI estimated reduction in wholesale-retail margins (projected to be reduced from $19.6 \%$ to $4.9 \%$ of prices in the presence of e-commerce) and computed the potential reduction in average effective price across all transactions that might be attained on products traded between Singapore and Japan (column two of Table 4). This varies by sector, depending on the degree of ecommerce penetration. It is highest for auto parts, which show a $1.39 \%$ reduction in average price.

\section{Services Trade}

The previously discussed aspects of the FTA - tariff reductions, customs automization and ecommerce - largely affect the cost of merchandise trade between Japan and Singapore. However, the FTA also proposes liberalization of services trade. Here, quantification is quite difficult, as data on services trade and potential barriers are rather scarce. For purposes of this study, we follow the recent work of Joseph Francois (1999) who has estimated two gravity models of trade - one for business services and one for construction services -- using bilateral services export data from the United States (BEA, 1999). 
Francois' gravity models permit him to predict what trade would be in the absence of barriers to trade - using Hong Kong and Singapore as "free trade" benchmarks. By positing an import demand function he is then able to obtain tariff equivalents for the unobserved trade barriers for services trade in business and finance and construction. Estimation results are reported in Table 5. As can be seen, Japan's estimated tariff equivalent of $20.6 \%$ is relatively high for business and financial services. The tariff equivalent for construction imports into Japan is even higher (29.9\%), although other countries have much more restrictive trade barriers in this sector.

We seek to quantify the services trade liberalization portion of the Japan-Singapore FTA by eliminating - on a bilateral basis - these services trade barriers. Since all of the barriers in Table 5 are measured relative to Singapore and Hong Kong, this liberalization once again does not affect Singapore. On the other hand, it lowers the effective price of business and financial services exported from Singapore to Japan by $20.6 \%$, and for constructions services the price drop is $29.9 \%$. Of course it should be noted that most of the biggest barriers to trade in services arise in the trade and transport sector (Hoekman, 1995), and we have ignored this altogether due to a lack of protection estimates. We also ignore prospective liberalization of investment and the movement of persons providing services - which are major vehicles for delivering services to foreign markets. In short, this quantification is quite limited and should be seen as providing a lower bound on potential impacts of the services component of the FTA between Japan and Singapore.

\section{Analytical Framework}

It has now become standard practice to use applied general equilibrium (AGE) models to analyze the likely impact of free trade agreements (Francois and Shiells, 1994). Due to the economywide nature of FTAs, it hardly makes sense to examine any given sector in partial equilibrium isolation; the interplay between sectors becomes a key aspect of such regional trade agreements. Their explicit incorporation of bilateral trade flows also makes AGE models well-suited to analyzing the 
consequences of preferential trade arrangements. Finally, their neoclassical theoretical foundations lend AGE models nicely to analysis of the trade-off between greater openness on the one hand, and potential trade diversion on the other. Accordingly, we use the AGE approach in this study.

In order to capture the dynamic effects of the "new age" FTA between Japan and Singapore, as well as the potential impacts on international investment flows and wealth, we utilize the newly developed, Dynamic GTAP model (Ianchovichina and McDougall, 2000). It is a recursive-dynamic extension of the standard GTAP model (Hertel, 1997). The Dynamic GTAP model (GTAP-Dyn) preserves all the standard features of the GTAP model -- perfect competition, Armington trade flows, disaggregated import usage by activity, non-homothetic consumer demands and explicit modeling of international trade and transport -- while enhancing the investment theory to incorporate international capital mobility and ownership. GTAP-Dyn uses the standard GTAP data base supplemented with foreign income data from the IMF Balance of Payments statistics in order to track international capital mobility and foreign wealth. In this paper we use a 17 region, 17 commodity aggregation of the GTAP database, version 4. The regions and commodities are listed in Appendix 1.

\section{Investment Theory}

The dynamic GTAP model uses a disequilibrium approach for modeling international capital mobility. This disequilibrium approach is necessary in order to reconcile the theory of investment with observed reality. Economic theory states that saving is allocated across regions to those investments with the highest rate of return. With perfect capital mobility, rates of return must be equalized across regions. However, empirical evidence indicates that this is not the case (e.g., Feldstein and Horioka, 1980). In the dynamic GTAP model, perfect capital mobility occurs only in the very long run. Investment is the result of the gradual movement of rates of return to equality across regions. This is the first use of the disequilibrium approach.

A corollary of the capital mobility theory is that if rates of return in a particular country are very low, investment will fall and vice versa. Implementation of this theory, however, leads to a dilemma. 
In many cases actual investment, as reported in the national statistics, does not correspond to that predicted by capital mobility. In particular, observed rates of return are low in some regions, while observed investment is high and vice versa. These discrepancies between observation and theory can be rectified in one of two ways: firstly, the data can be altered so that theory and data become consistent; or alternatively, the theory can be modified to more accurately reflect the world. In the dynamic GTAP model the latter method has been used. This has been achieved by incorporating errors in expectations about the actual rate of return. These errors are gradually eliminated over time. This is the second use of disequilibrium in the modeling of international capital mobility. Those interested in further details about the Dynamic GTAP model are referred to Ianchovichina and McDougall (2000).

\section{Foreign Capital Ownership}

With the incorporation of international capital mobility it becomes necessary to take account of foreign capital ownership. This is especially important in East Asia, where international investment has boomed in recent decades with the outsourcing of production from Japan and other high wage economies. In the dynamic GTAP model, regional capital is owned either by domestic households or by foreign households - with the latter's ownership mediated via a global trust. (We do not have data on bilateral patterns of foreign ownership.) The saving of each regional household is then allocated either to domestic investment or to foreign investment. The allocation of savings in the model respects the observed home bias in equity portfolios (e.g., French and Poterba, 1991). Specifically, it is assumed that the initial shares of domestic and foreign investments are held constant, subject to the adding-up conditions required to ensure regional saving and investment accounting constraints.

Explicit modeling of the ownership of regional investment in Japan and other Asian economies allows the accumulation of Japanese wealth by foreigners to be determined. In addition Japan's ownership of domestic and foreign assets can also be tracked. Income accruing from the ownership 
of these foreign and domestic assets can then be appropriately incorporated into total regional income, and hence the computation of welfare for Japan, Singapore and the rest of the world.

\section{Treatment of Unobserved Trade Costs}

As we saw above, a key feature of the proposed "new age" FTA between Japan and Singapore involves a series of measures intended to lower non-tariff trade costs between the FTA members. Yet many of these trade costs (e.g., the costs of customs clearance) are not explicitly in the data base. How can we introduce these non-tariff shocks and analyze their likely impact on trade flows? The approach we have taken is to introduce the notion of an "effective price" of commodity $i$, imported from country $r$ at domestic prices in destination market $s: P M S_{i r s}^{*}$. This is related to the observed price, $P M S_{\text {irs }}$, as follows: $P M S^{*}=P M S / A M S$. The technical coefficient $A M S$ is unobserved, and equal to one in initial equilibrium. Changes in its value capture the impact of non-tariff measures on the price of imports from a particular exporter. Thus an increase in $A M S_{i r s}$ ensures a fall in the effective domestic price of good $i$ exported from $r$ to $s$. In order to ensure a balanced data set, a compensating quantity adjustment is required, so we define the "effective quantity" of exports associated with this price: $Q X S^{*}=Q X S \cdot A M S$. Therefore, the product of observed price and quantity, equal the product of effective price and quantity. And trade balance is maintained.

When this theory is incorporated into the GTAP model, and the import price and demand equations are totally differentiated and placed in percentage change form (denoted by lower case variables), we obtain the revised equations (1) and (2) reported below.

Import Demand Equation

$q x s_{i r s}=-a m s_{i r s}+q i m_{i s}-\sigma_{m}^{i} \cdot\left[p m s_{i r s}-a m s_{i r s}-p i m_{i s}\right]$

Composite Import Price Equation

$\operatorname{pim}_{i s}=\sum_{k} \theta_{i k s} \cdot\left[p m s_{i k s}-a m s_{i k s}\right]$ 
where:

$\sigma_{m}^{i}$ : elasticity of substitution among imports of $i$

$q x s_{i r s}$ : percentage change in bilateral exports of $i$ from $r$ to $s$

$\operatorname{qim}_{i s}:$ percentage change in total imports of $i$ into $s$

$p m s_{i r s}$ : percentage change in price of imports of $i$ from $r$ in $s$

$\operatorname{pim}_{i s}$ : percentage change in average import price of $i$ in $s$

$a m s_{i r s}$ : percentage change in effective price of $i$ from $r$ in $s$ due to change in unobserved trade costs

From equations (1) and (2), we can see that the impact of a shock to the new variable can be seen to have three distinct effects. Firstly, from the import demand equation, we see that a one percent shock to $a m s_{i r s}$ will lower the effective price of imports of good $i$ from exporter $r$ imported into country $s$, thereby inducing substitution towards this exporter and away from other exporters, as governed by the elasticity of substitution: $\sigma_{m}^{i}$. However, there is a second effect in the same equation, which works in the opposite direction. Since the effective quantity of the good has also increased, less is required to meet the needs of the importer. Finally, from the composite import price equation, we can see that a one percent shock to $a m s_{i r s}$ will lower the average import price, thereby encouraging an expansion of imports at the expense of domestic purchases. While the total impact on imports is uncertain in theory, given the values of the trade elasticities in GTAP, we expect a reduction in trade costs to increase both observed expenditures on imports and the share of imports from the FTA partner to which this reduction in trade costs is applied.

\section{Baseline}

In order to establish the impact of the prospective Japan-Singapore FTA, we must begin by developing a baseline to show what the world economy would look like without the FTA imposed. 
This gives us two time paths for each variable of interest: firstly, a path which shows how the variable would change over time without the free trade agreement; and secondly, a path which shows how the variable would change with the free trade agreement. The difference between the two paths shows the effect of the free trade agreement. Typically these differences are cumulated and then plotted against time to illustrate the impact of the FTA on a given variable.

The baseline scenario used in this paper is based on the baseline developed by Walmsley, Dimaranan and McDougall (2000) at the Center for Global Trade Analysis, based on input from the World Bank and several other international organizations. It contains information on macroeconomic variables as well as expected policy changes over the 1995- 2020 period. The macroeconomic variables in the baseline include observations or projections for real gross domestic product, gross investment, capital stocks, population, skilled and unskilled labor and total labor (see Appendix 2). By way of illustration, Figure 2 shows the growth rates in real GDP over the 1995-2007 period, for Japan, Singapore, Korea and China. Higher GDP growth tends to translate into higher growth in trade - both for imports and exports, ceteris paribus. In the baseline, post-crisis growth rates are positive but quite low for Japan, relative to Korea and Singapore. China's growth remains very strong out to 2007 under this baseline.

The specification of policies in the baseline is very important for our FTA analysis. For example, as tariffs come down worldwide, under the implementation of the Uruguay Round Agreement, the potential for trade diversion is reduced. This is because the remaining preference margin is smaller in the wake of lower MFN tariffs. The policies included in the baseline are those which are expected to occur within the region. They are summarized in Table 6 . The aim here is to develop a realistic policy scenario for the free trade experiments undertaken here.

Uruguay Round tariff commitments are assumed to be honored by all countries. However, due to the presence of dirty tariffication in agriculture (Ingco, 1996), it is assumed that there would be no further effective liberalization in agriculture from measured levels of protection in 1995. China and Taiwan are assumed to join the WTO, with their accession offers phased in over the 2000-2005 
period. This accession also gives them quota free access to the North American and European textile and apparel markets by 2005 . However, the liberalization of these quotas is assumed to be heavily back-loaded with most of the liberalization occurring after 2002 (Francois and Spinanger, 2001).

\section{Results}

It is the aim of this paper to examine the relative importance of the various components of the Japan-Singapore FTA, as well as their combined effect on international trade, investment flows and growth in these two economies. Towards this end, four FTA simulations were undertaken. Each one adds another dimension of the FTA, thereby permitting an assessment of each part of this prospective agreement. The first simulation simply involves the removal of tariffs between these two trading partners. The next three simulations successively add further "new age" features of the JapanSingapore FTA, including: the liberalization of direct trade in business services and construction, the implementation of improved security and common standards for e-commerce between Japan and Singapore, and finally, modern, web-based, customs clearance procedures designed to automate this aspect of international trade in Japan.

\section{Impacts on Singapore}

Figure 3 shows that all four of these components of the Japan-Singapore FTA lead to higher rates of return on investment in Singapore. The tariff cuts (largely in Japan) boost the demand for Singaporean products, thereby raising returns to capital in that economy. The time profile of this effect is shown by the shaded area at the bottom of the bars in Figure 3 (tariff only). The rise in rate of return encourages additional investment - both domestically and by foreigners - and the additional investment eventually brings the rate of return back down to that attained in the baseline simulation. Indeed, the FTA rate of return actually falls slightly below its baseline level, before rebounding after 2015. Eventually all rates of return are equalized due to perfect capital mobility. But this is only attained in the very long run. 
The reduction in barriers to Singapore's direct exports of services to Japan has a similar effect to that of tariffs on the rate of return. This may be seen by considering the incremental effect shown by the second set of bars in Figure 3 (tariffs plus services). Judging from the gap between rate of return effect under the tariffs-only simulation and that under the tariffs and services simulation, services liberalization is somewhat more important for the rate of return.

Unlike the one-sided trade liberalization measures, the e-commerce and customs automization shocks affect both the demand for Singaporean products in Japan, as well as the cost of Japanese imports in Singapore. By lowering the cost of investment goods in Singapore, there is an added boost to the rate of return. Not only has the rental rate on capital risen - due to increased demand for Singaporean products in Japan - but the cost of investing in Singapore has fallen. This is particularly true of customs automization which lowers the effective price of Japanese machinery and equipment in Singapore. As a consequence, these "new age" features of the FTA contribute the majority of the change in rate of return in Singapore.

The increased investment in Singapore, due to the higher rates of return over the 2006-2010 period, dominates the increase in national savings as a result of higher incomes. Therefore Singapore's trade balance deteriorates, relative to the baseline simulation. This is shown in Figure 4. The deterioration reaches its peak in 2008, after which it begins to improve. This reflects the fact that rates of return fall back to their baseline levels and the increase in foreign wealth invested in Singapore gives rise to larger foreign income payments - thereby requiring higher levels of exports, relative to the baseline.

Figure 5 summarizes the long run impact of the Japan-Singapore FTA by reporting the cumulative difference between the FTA and baseline simulations in 2020, for a variety of macroeconomic variables of interest. These include: real GDP, capital stock, exports, imports and foreign ownership. The higher rates of return due to the FTA give rise to a large increase in foreign ownership (2.7\% by 2020), as well as higher capital stocks and GDP. The increase in GDP is larger than the share-weighted increase in capital stock due to the efficiency improvements generated by the 
"new-age" elements of the FTA. Not surprisingly, both exports and imports are also higher in 2020, although their rates of increase are much smaller than for Foreign Ownership. This indicates the importance of this "new age" FTA for foreign investment - as well as trade.

Given the importance of this FTA for investment and capital stocks, it is interesting to focus specifically on the resulting changes in the wealth of Singaporean households. This is highlighted in Figure 6 . The line connecting the triangular dots in this figure illustrates the cumulative \% difference between the base case and FTA simulation for the total wealth of Singaporean households. This shows that total wealth rises due to the FTA, and all four elements of the FTA contribute to this increase. However, Singaporean wealth is divided amongst domestic equity and foreign equity. Not surprisingly, Singaporean households choose to invest more in their own country and less in foreign countries as the domestic rate of return rises.

Table 8 reports the impacts of the FTA on Singapore's trade with Japan as well as with ROW (all other countries combined). The figures in the table represent cumulative changes in 2020 trade volumes in millions of \$US. Percentage changes are reported in parentheses. The biggest volume changes in Singapore's exports to Japan are in machinery and equipment (\$1,514 million), followed by business and finance services and other food products. There are large percentage changes in meat products $(418 \%)$, leather, and textiles and apparel, but the initial trade flows are small for these products and so the volume change is also small. However, these large percentage changes indicate a very substantial preference margin for Singaporean goods exported to Japan. This, in turn, signals the potential for trade being routed from third countries, through Singapore to Japan. Hence the interest in strong rules of origin on the part of food and light manufactures producers in Japan.

In contrast, the percentage changes in Singapore's imports from Japan are much more uniform, with the largest changes stimulated by the combined benefits of e-commerce and customs automization for auto imports from Japan (12.6\% increase in bilateral imports) and imports of machinery and equipment. Due to its predominant role in Japanese exports to Singapore, the increased volume in the latter sector $(\$ 2,905$ million) is by far the largest change in Singapore's 
bilateral imports from Japan. Finally, Singapore's imports from the rest of the world rise across the board - indicating this FTA package is not leading to diversion of trade.

Table 9 reports the changes in 2020 volume of output (\$US millions) in Singapore across the four, cumulative simulations. While individual components of the FTA lead to output declines in a few cases, when combined with customs automization, almost all sectors increase their output levels in 2020. (Other crops experience a very small decline in output.) Typically in the case of such FTAs one sees winners and losers - so it is surprising that there is no significant contraction of output across the sectors shown in Table 10. This is due to the growth effects of the FTA. The increase in capital stock available in Singapore, coupled with the relative balanced import effects, permits the simultaneous expansion of nearly all sectors of the economy.

\section{Results for Japan}

The impacts of the FTA on Japan have a distinctly different character than those for Singapore. Japan's exports to Singapore represent only $3.2 \%$ of total trade. Therefore, the strictly bilateral measures, including: tariff cuts, reduced services trade barriers and e-commerce regulations, have a relatively minor impact on aggregate output, trade, investment and GDP. Rather, the impacts of the FTA on Japan are driven largely by the customs automization process, which affects the cost of trading with all partners. This may be seen in Figure 7 which reports the impact of individual components of the FTA on the rate of return on investment in Japan. The cumulative effect of the first three (bilateral) elements of the agreement are negligible when compared to the impact of customs automization. The latter reform boosts rates of return in Japan, by increasing efficiency in the economy, and this gives rise to a capital inflow (recall that this was also the case in Singapore). As a result, Japan's trade balance deteriorates, relative to the baseline (Figure 8). However, in the long run, increased foreign income payments dictate an increase in exports, so that we observe the same Ushaped pattern for the trade balance change, relative to the baseline, as we saw for Singapore.

The long run impacts of the Japan-Singapore FTA on other macro-economic variables in the Japanese economy are reported in the second row of Table 7. Whereas the investment and GDP 
results dominated the aggregated trade volume effects in Singapore, in Japan, where customs automization lowers the cost of trade with all partners and the trade/GDP ratio is much smaller, the trade volume changes dominate. Specifically, Japan's exports are projected to be nearly two percent higher, relative to baseline, in 2020. Capital stocks and wealth are about one-third of a percent higher in the wake of the FTA, while Japan's GDP gets a modest $0.2 \%$ cumulative boost by the year 2020 .

The modest macro-economic effects are mirrored at the sector level. While bilateral imports from Singapore receive a considerable boost - particularly for primary products and light manufactures (recall Table 8), the subsequent changes in Japanese output are quite small and reflect a shift towards Japan's comparative advantage in durable goods production (Table 9). The largest output volume declines in Japan are for textiles and apparel (-\$746 million), other food and meat products. However, the only decline in excess of one percent, relative to baseline, is for other grains $(-1.02 \%)$. As was the case with Singapore, trade with ROW increases, with the only declines in Japanese imports from ROW coming in other grains and in business and finance services (Table 8).

\section{Results for Rest of World}

The remaining rows of Table 7 report the impact of the Japan-Singapore FTA on the macroeconomic performance of countries outside the FTA. The automization of custom's procedures increases trade throughout the Asia-Pacific region and the rest of the world, thus boosting real GDP in all regions excepting for Canada, Western Europe and the residual region in the final row of this table. All of the Asian economies gain in terms of real GDP - with the largest impact felt in Thailand and Malaysia - two economies that trade a great deal with Singapore and Japan. These increases in real GDP also fuel increased foreign investment, with the stock of foreign-owned equity in Thailand rising by $1.7 \%$ as a result of the FTA. The increase in foreign ownership in Singapore, Japan and Thailand is financed by a modest increase in outward foreign direct investment (FDI) by the US, Canada, Mexico, China and South Asia, as reported in the final column of Table 7. Many of the other Asian economies reduce their foreign ownership in order to increase investment in their domestic economies. 


\section{Welfare Effects}

A natural question to ask in the face of any Free Trade Agreement is the following: Does it leave the world as a whole better off? Given the multi-region, multi-period nature of this study, we face the challenging problem of aggregating benefits over countries and over time periods. To keep things simple, we focus on welfare at a particular point in time - in this case we choose 2020 - at which point the investment story has played itself out. We then compute the static equivalent variation, for the representative household in each region, associated with the cumulative changes that have occurred between the baseline and the FTA simulations. These dollar values represent the annual increase (or decrease) in real income stemming from the presence of the FTA. The simple sum of these EV measures is our annual measure of the change in world welfare.

Equivalent variations for each region and for the world as a whole are reported in Table 10. Here, each of the first four columns corresponds to one of the four components of the FTA. (The final column reports the per capita percentage changes in welfare due to the FTA. This will be discussed below.) The traditional, bilateral tariff elimination associated with most FTAs generates global welfare losses, as the only significant bilateral tariffs remaining are Japan's tariffs on primary products and light manufactures. Taken on their own, elimination of these tariffs creates costly trade diversion, with increased imports coming from Singapore at the expense of lower cost suppliers elsewhere. Singapore's welfare rises as a result of the terms of trade gain that they experience. However, Japan's welfare falls, as does that for all other countries.

As one moves from this traditional tariff-based FTA to the "new age" elements that focus less on commercial policy and more on improving efficiency, the prevalence of regional benefits increases. In the case of services trade liberalization, both Japan and Singapore gain and the overall benefits outweigh the costs, generating a global welfare gain of \$206 million. In the case of e-commerce, the gains are spread across more than half of the trading partners. Finally, in the case of the customs automization component of the FTA, all regions gain. In fact, the latter component dominates all of the others, and consequently, all regions benefit from the FTA. 
The very favorable outcome from customs automization has several explanations. Firstly, this is the only FTA measure that is non-discriminatory. Customs automization benefits all trading partners. Of course, the "linking benefit" derived from two countries synchronizing their systems gives an additional margin of preference to Japan -Singapore trade. However, eventually other countries that implement this system will also obtain this linking effect. Secondly, unlike tariff cuts which lead to lost revenue, customs automization saves time and hence lowers the effective price of the product. There is no lost revenue - apart from the cost of implementation - so the liberalizing country is unlikely to experience a loss in welfare.

This raises the question: if customs automization is such a windfall, why hasn't it already been implemented? One answer is that, like many administrative reforms, the barriers to reform are not merely economic. A second, more interesting, answer is that the direct benefits of customs automization are quite small, and the costs are non-negligible. The Mitsubishi Research Institute (MRI) estimates that the cost of running the new system will be $\$ 36.7$ million/year. It is only when the indirect benefits -- specifically the opportunity costs of time in trade -- are taken into account, that this becomes an important feature of the FTA. To date, this particular barrier to trade has received scant attention. Hence the importance of Hummels' (2000) work in quantifying the ad valorem value of time savings in trade.

The final column of Table 10 reports the percentage changes in per capita welfare in each region of the world as a result of the FTA. Unlike the EV measure, this controls for economic size when making comparisons across regions. Not surprisingly, Singapore is the largest per capita winner from the FTA. Singapore is a very open economy, trade with Japan is quite important, and Singapore receives a substantial preference margin on tariffs, services trade, and e-commerce, as well as a linking benefit associated with Japan's customs automization measures. More surprising is the fact that Thailand and Malaysia gain relatively more from the FTA than does Japan. This, despite the fact that they are not directly included in the FTA. The reason for these large gains is their relatively high trade dependence on Japan and Singapore, both of which are importing more from all destinations as 
a result of the agreement. Japan's imports rise as a result of customs automization. Singapore's imports rise in response to the increased demand for its own products in the Japanese markets, as well as due to higher incomes. The subsequent increase in demand for products from Thailand and Malaysia give rise to substantial terms of trade gains for both economies.

\section{Summary and Conclusions}

This study has sought to quantify the dynamic benefits of Japan's "new age" Free Trade Agreement currently under negotiation with Singapore. We find that the impact of the FTA on investment, capital accumulation and economic growth is significant - particularly in Singapore. Furthermore, global benefits from the proposed FTA are substantial - on the order of $\$ 9.5$ billion/year by 2020 . All regions of the world gain from this agreement, although $70 \%$ of the gains are captured by Japan - which is the region undertaking most of the reforms.

It is interesting to note that if the FTA were implemented as a traditional trade agreement with tariff cuts being the centerpiece - perhaps adding some liberalization of rules governing direct trade in services - none of this would be true. The global welfare gains would be uncertain, trade diversion would be significant, and most non-participating regions would lose from the agreement. It is only when the "new age" features - e-commerce and customs automization - are added that benefits to the other regions begin to appear and the global gains become pronounced.

In closing, it is important to note the limitations of this study. Firstly, since this work was begun, a number of aspects of the agreement have become clearer. In particular, it is likely that agriculture will be left out of the agreement - due to the problem of enforcing rules of origin on these heavily protected products. Also, the timetable for implementation has been moved up to begin in spring 2002, if all goes as planned. Since agriculture generates relatively few of the gains in our study, its omission unlikely to have a substantial impact on our results. Similarly, we have found that the results are quite robust with respect to the baseline. The main developments between 2002 and 2005 in our baseline are China's accession to the WTO and elimination of the textiles and apparel export quotas. Neither 
of these has direct bearing on the Japan-Singapore trade relationship and results not reported here show that China's accession makes little difference for the direct impacts of this FTA on the member economies.

Despite our best attempts to quantify "new-age" features of the Japan-Singapore FTA, there remain a number of important elements of this agreement that we have omitted. Specifically, we have not incorporated the effects of liberalization of direct trade in transport and telecommunications services where barriers are potentially quite large. We have also failed to quantify the impact of liberalizing rules governing investment and the movement of natural persons. These are central modes of delivery for the rapidly growing services sector, and their omission surely leads to an understatement of the impacts of the FTA on efficiency, investment and growth.

Finally, while there are many potential benefits of the proposed FTA between Japan and Singapore, there are also some costs that have been neglected. Several elements of the FTA will involve implementation costs. Also, customs automization will involve recurring costs of about $\$ 37$ million/year (MRI estimate). However, these are small when compared with the potential gains. Perhaps of greater concern are the costs associated with verifying that the products granted preferential treatment under the FTA in question are indeed produced in the partner country. This issue is of particular concern in the case of food products, textiles, apparel and leather products under the Japan-Singapore FTA. Japan's tariffs in these sectors are still high and, given the high volume of re-exports from Singapore, the potential incentive for other countries to export foodstuffs and light manufactures through Singapore to Japan would be substantial. Very tight rules of origin that would prevent such transshipment could also prove costly to the businesses involved, thereby frustrating trade. 


\section{References}

Ahuja, V. and D. Filmer. (1995). "Educational Attainment in Developing Countries; New Estimates and Projections Disaggregated by Gender," World Bank Policy Research Working Paper 1489, Washington, DC, July.

Anderson, K. and H. Norheim. (1993). "Is World Trade Becoming More Regionalized?" Review of International Economics 1(2):91-109.

Brown, A.J. (1949). Applied Economics: Aspects of the World Economy in War and Peace, London: George Allen-Unwin.

Bureau of Economic Analysis. (1999) International Accounts Data U.S. International Services: Cross-Border Trade \& Sales Through Affiliates, 1986-99, (http://www.bea.doc.gov/bea/di/1000serv/intlserv.htm)

Central Intelligence Agency. (1997). The World Factbook 1997-1998. Brassey's: Washington.

CPB. (1999). "WorldScan: the Core Version," CPB Netherlands Bureau for Economic Policy Analysis, December.

Dee, P. and K. Hanslow. (2000) "Multilateral Liberalisation of Services Trade," Staff Research Paper, Productivity Commission, Australia.

Drysdale, P. (1967). Japanese-Australian Trade, Ph.D. Dissertation. Australian National University, Canberra.

Drysdale, P. and R. Garnaut. (1982). "Trade Intensities and the Analysis of Bilateral Trade Flows in a Many-Country World", Hitsubashi Journal of Economics 22(2):62-84.

Fan, M. and Y. Zheng. (2000). "China's Trade Liberalisation for WTO Accession and Its Effects on China - A Computable General Equilibrium Analysis", mimeo.

Feldstein, M. and C. Horioka (1980). "Domestic Saving and International Capital Flows", The Economic Journal, Vol.90, June: 314-329.

Francois, J. (1998). "Scale Economies and Imperfect Competition in the GTAP Model", GTAP Technical Paper No. 14, Center for Global Trade Analysis, September.

Francois, J. (1999). "A Gravity Approach to Measuring Services Protection". Unpublished manuscript, Erasmus University, Rotterdam.

Francois, J. and C. Shiells. (1994). Modeling Trade Policy: Applied General Equilibrium Assessments of North American Free Trade. Cambridge University Press.

Francois, J. and D. Spinanger. (2001). "With Rags to Riches But Then What?" paper presented at the Fourth Annual Conference on Global Economic Analysis, West Lafayette, June 27-29, 2001.

Francois, J. and A. Strutt. (1999). "Post Uruguay Round Tariff Vectors for GTAP v.4," memo, June.

French, K. and J. Poterbe. (1991). "Investor Diversification and International Equity Markets", American Economic Review 81:222-26.

Harrison, W J and K. R. Pearson. (1996). "Computing Solutions For Large General Equilibrium Models Using GEMPACK”, Computational Economics 9:83-127.

Harrison, J., M. Horridge, and K. Pearson (1999) "Decomposing Simulation Results with Respect to Exogenous Shocks", paper presented at the Second Annual Conference on Global Economic Analysis, Denmark, June 20-22, 1999. 
Hertel, T. W. (1992). "Introducing Imperfect Competition into the SALTER Model", Purdue University, Department of Agricultural Economics Staff paper No. 93-3.

Hertel, T. W. (1997). Global Trade Analysis: Modeling and Applications, Cambridge University Press, Cambridge.

Hoekman, B. (1995). "Assessing the General Agreement on Trade in Services," in Martin, W. and Winters, L. A. eds. The Uruguay Round and the Developing Economies, World Bank Discussion Paper 307, World Bank, Washington DC.

Hummels, D. (2000). "Time as a Trade Barrier", unpublished manuscript, Purdue University, W. Lafayette, IN.

Ianchovichina, E. I. (1998). "International Capital Linkages: Theory and Applications in A Dynamic Computable General Equilibrium Model," Ph.D. Dissertation, Purdue University.

Ianchovichina, E. I., and R. A. McDougall. (2001). "Theoretical Structure of Dynamic GTAP" GTAP Technical Paper No. 17, Center for Global Trade Analysis, Purdue University, West Lafayette, IN, 47906-1145, USA.

IDE-JETRO. (2000). "Toward Closer Japan-Korea Economic Relations in the $21^{\text {st }}$ Century."

(http://www.ide.go.jp/English/Lecture/pressmenu/pressE000606.html)

Ingco, M. (1996). "Tariffication in the Uruguay Round: How Much Liberalization?" The World Economy, 19(4): 425-47, July.

Joint Study Group (2000). Report on the Free Trade Agreement between Japan and Singapore, Ministry of Foreign Affairs, Japan and Singapore.

Joint Study Group (2000) "Japan-Singapore Economic Agreement for a New Age Partnership", Japan Study Group Report (http://www.mofa.go.jp/region/asia-paci/singapore/econo b.html)

Kawasaki, K. (1999) Foundations and Applications of Applied General Equilibrium Analysis: A Simulation Analysis on Economic Structural Reform, Nihonhyohronsya.

Kojima, K. (1964). "The Pattern of International Trade among Advanced Countries", Hitsubashi Journal of Economics 5(1).

Korea Institute for International Economic Policy (KIEP). (2000). "Economic Effects of and Policy Directions for Korea-Japan FTA."

Martin, W., B. Dimaranan and T. Hertel, (1999): “Trade Policy, Structural Change and China's Trade Growth", mimeo.

McDougall, R.A., A. Elbehri, and T.P. Truong. (1998). Global Trade Assistance and Protection: The GTAP 4 Data Base, Center for Global Trade Analysis, Purdue University.

Nakajima, T. and Kwon, O. (2001). "An Analysis of the Economic Effects of Japan-Korea FTA", Economic Research Institute for Northeast Asia (ERINA).

Tsutsumi, M. (2000) "Regional Economic Integration an China's Participation to WTO," JCER Discussion Paper No. 60.

Walmsley, T. L., B. Dimaranan and R. A. McDougall, (2000) "A Base Case Scenario for the Dynamic GTAP Model." Paper prepared for the Dynamic GTAP Short Course, Purdue University, West Lafayette, IN, October.

WTO (2000) Trade Policy Review: Singapore, Geneva. 
Figure 1.1 Japanese Export Bias: Total Merchandise Trade

Source: Authors' Computations

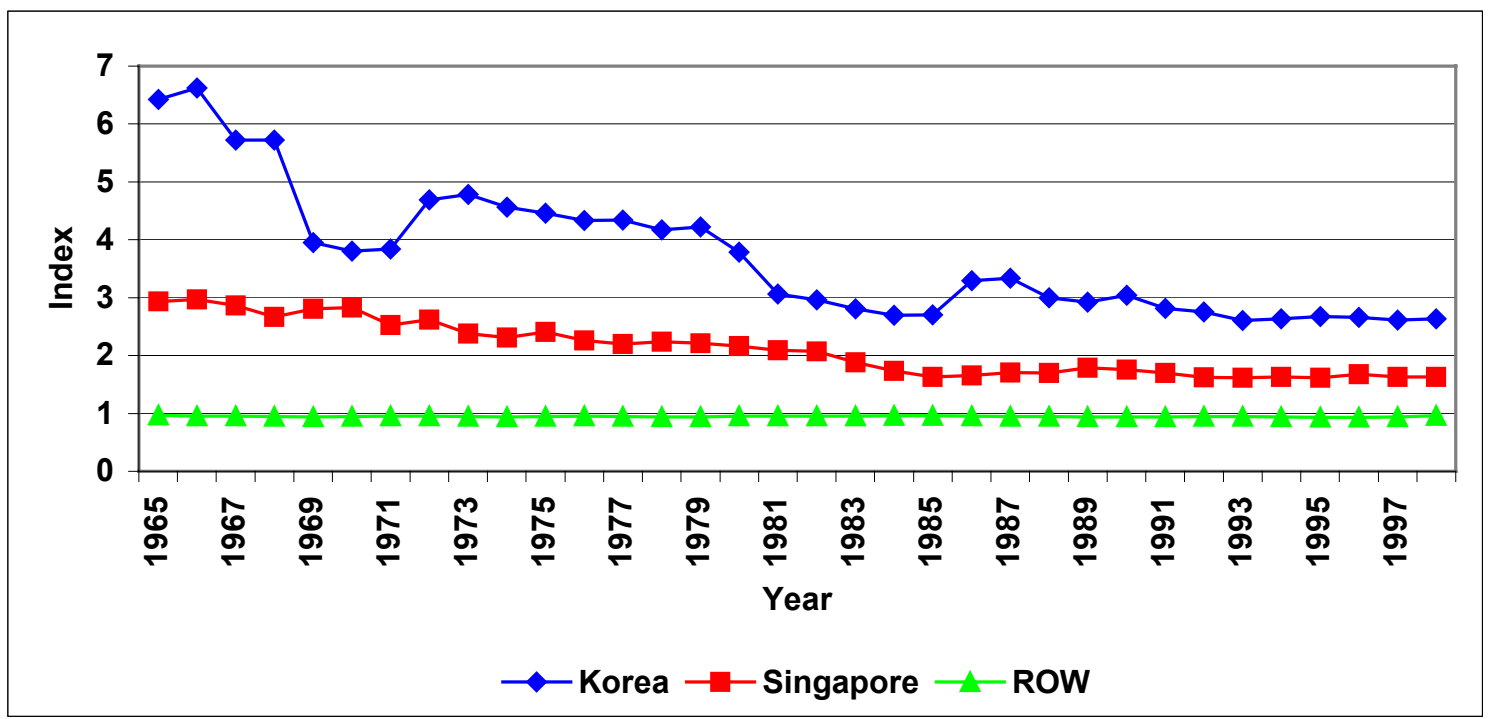

Figure 1.2 Korea and Singapore Export Biases to Japan

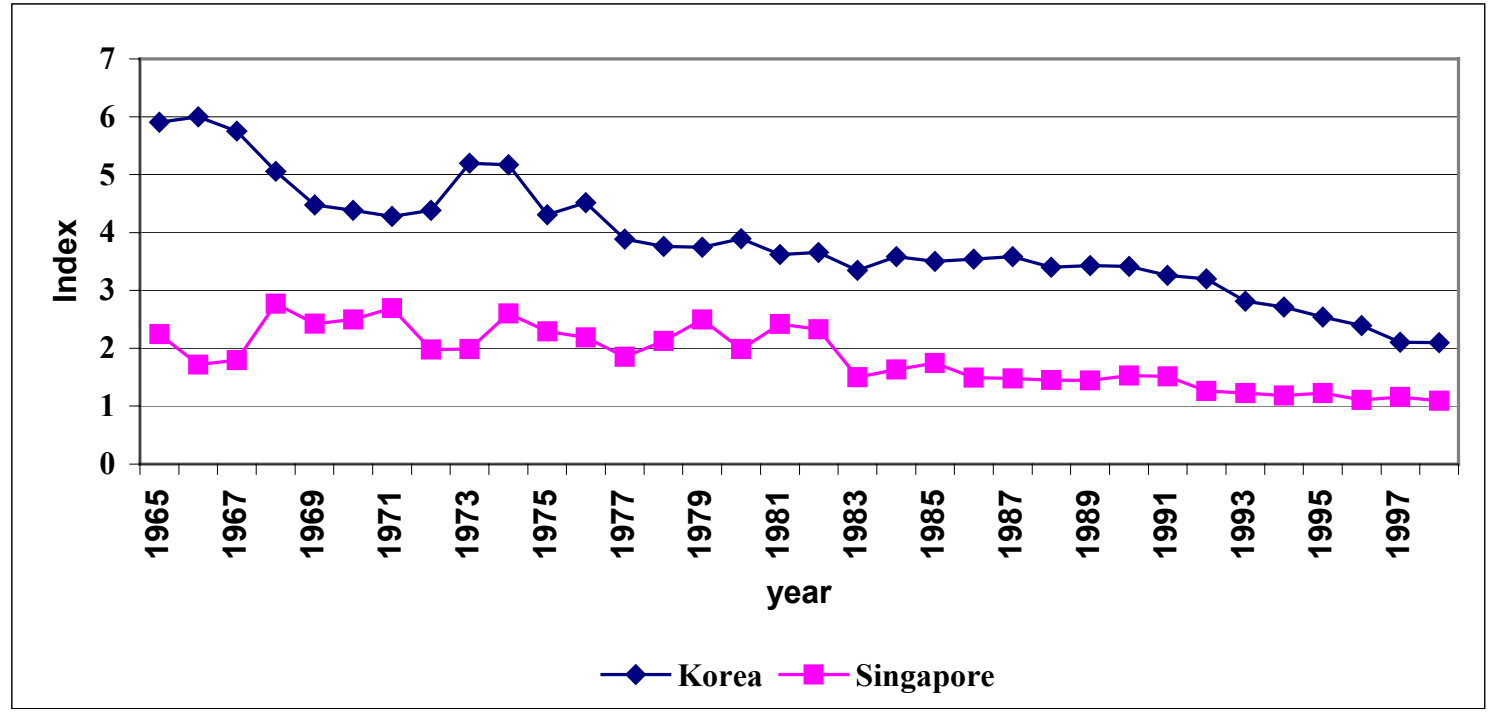

Source: Authors' Computations 
Figure 2. Growth in Real GDP: Baseline

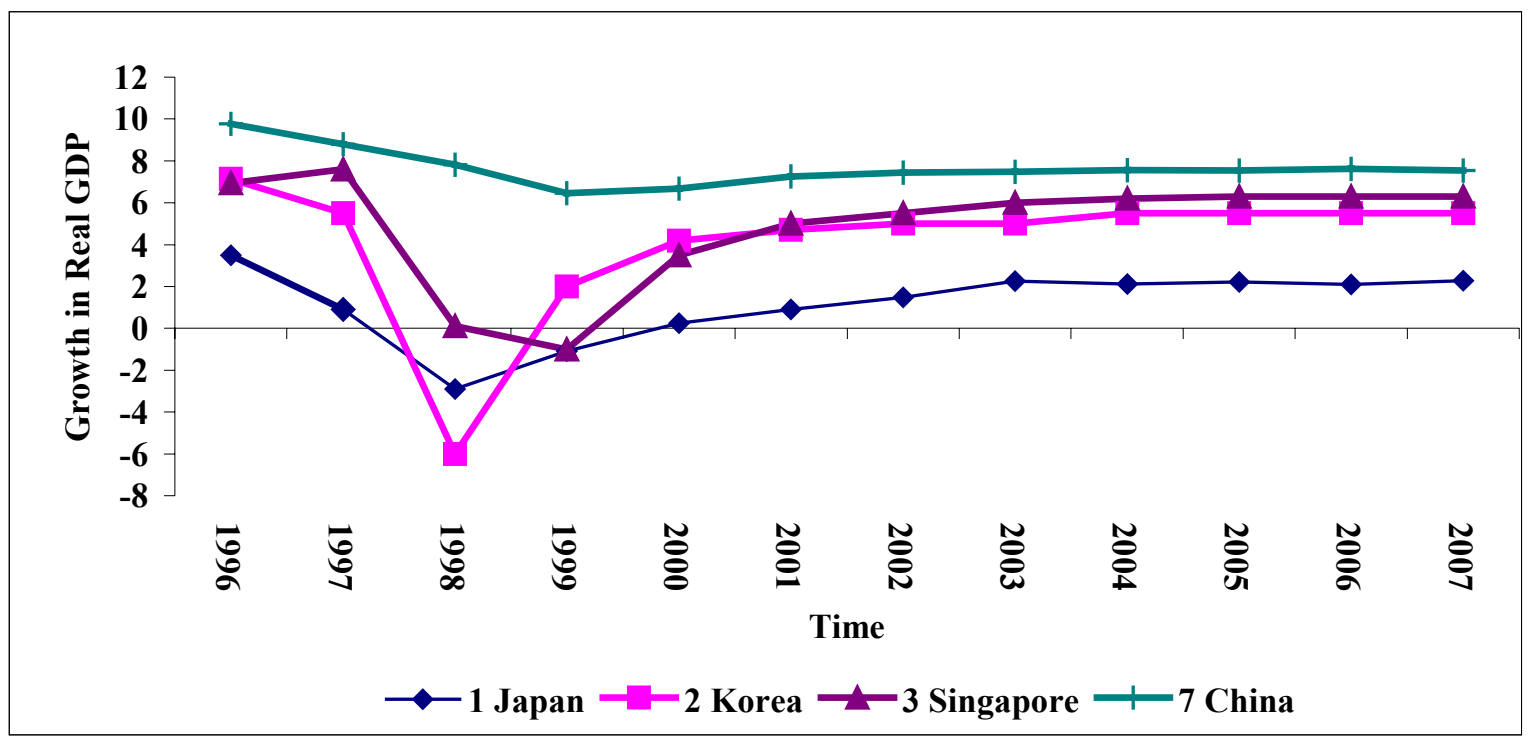

Figure 3. Effect of Japan-Singapore Free Trade Agreement on the Rate of Return in Singapore

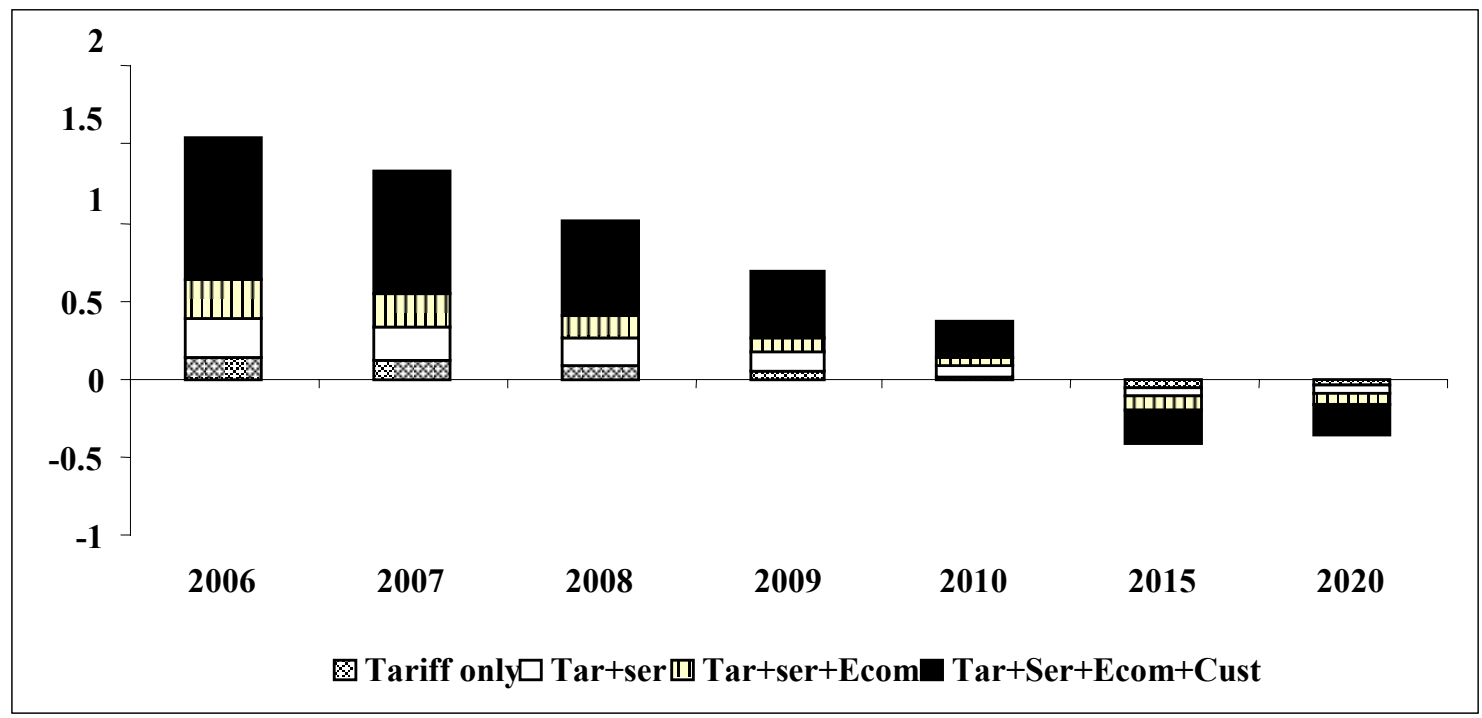


Figure 4. Effect of Japan-Singapore Free Trade Agreement on Singapore's Trade Balance

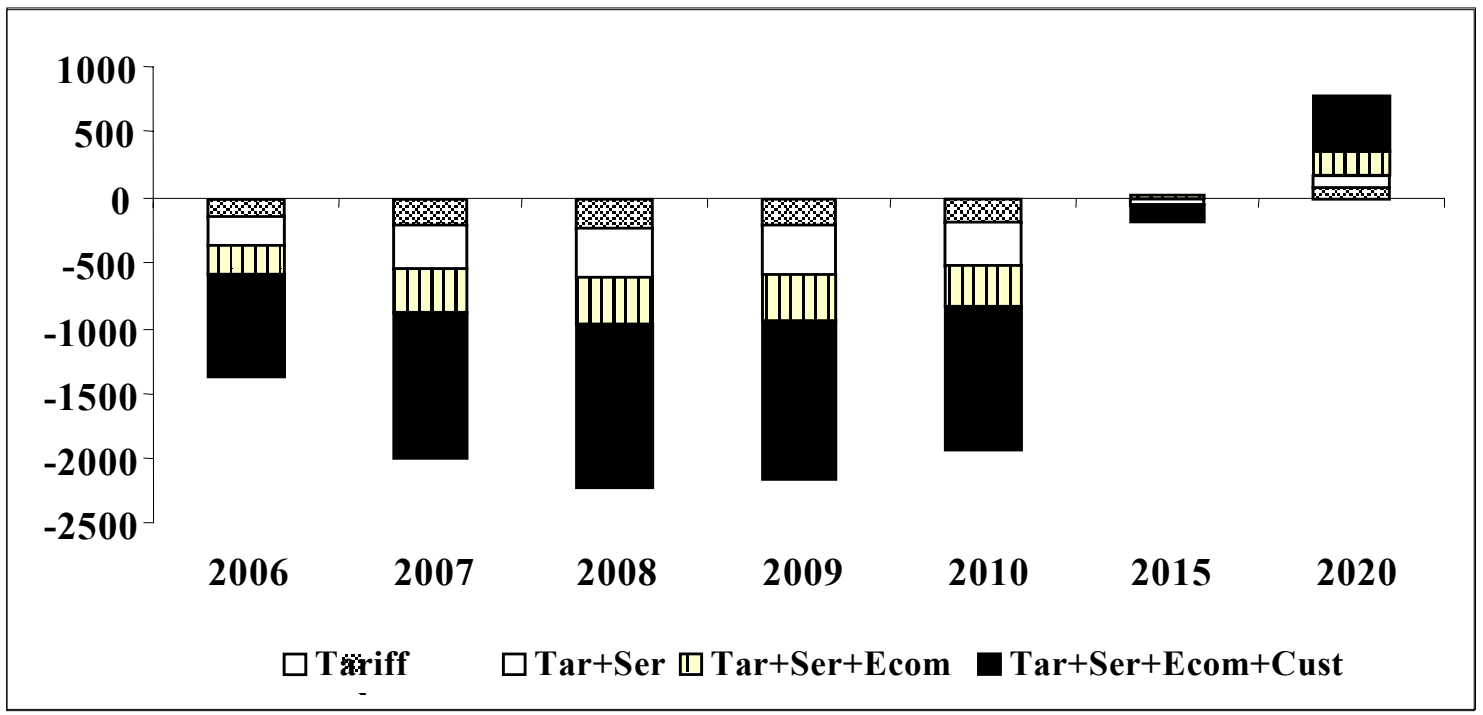

Figure 5. Effect of Japan-Singapore Free Trade Agreement on Singapore's Real GDP, Capital, Exports and Imports and Foreign Ownership in Japan

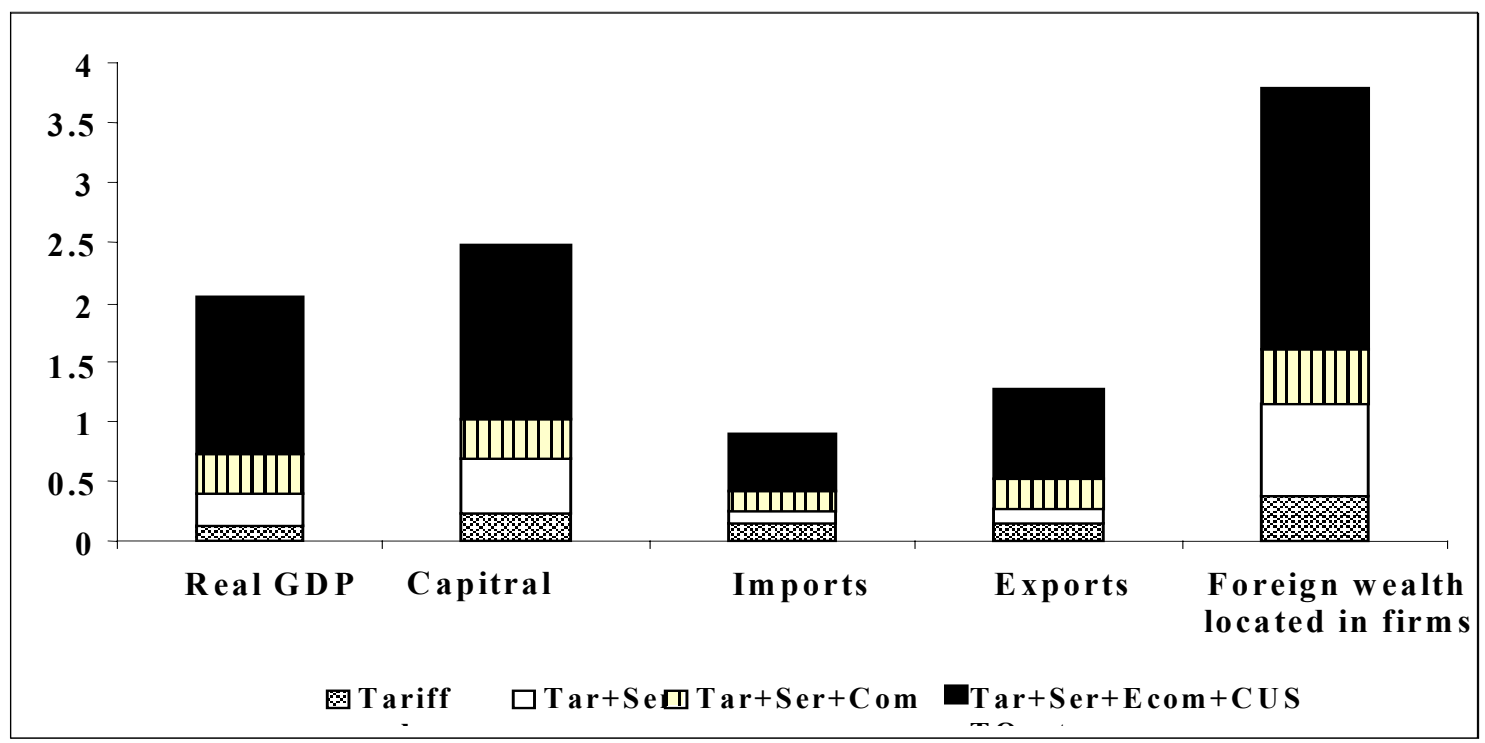


Figure 6. Effect of Japan-Singapore Free Trade Agreement on the Wealth of Singaporean Households ${ }^{1}$

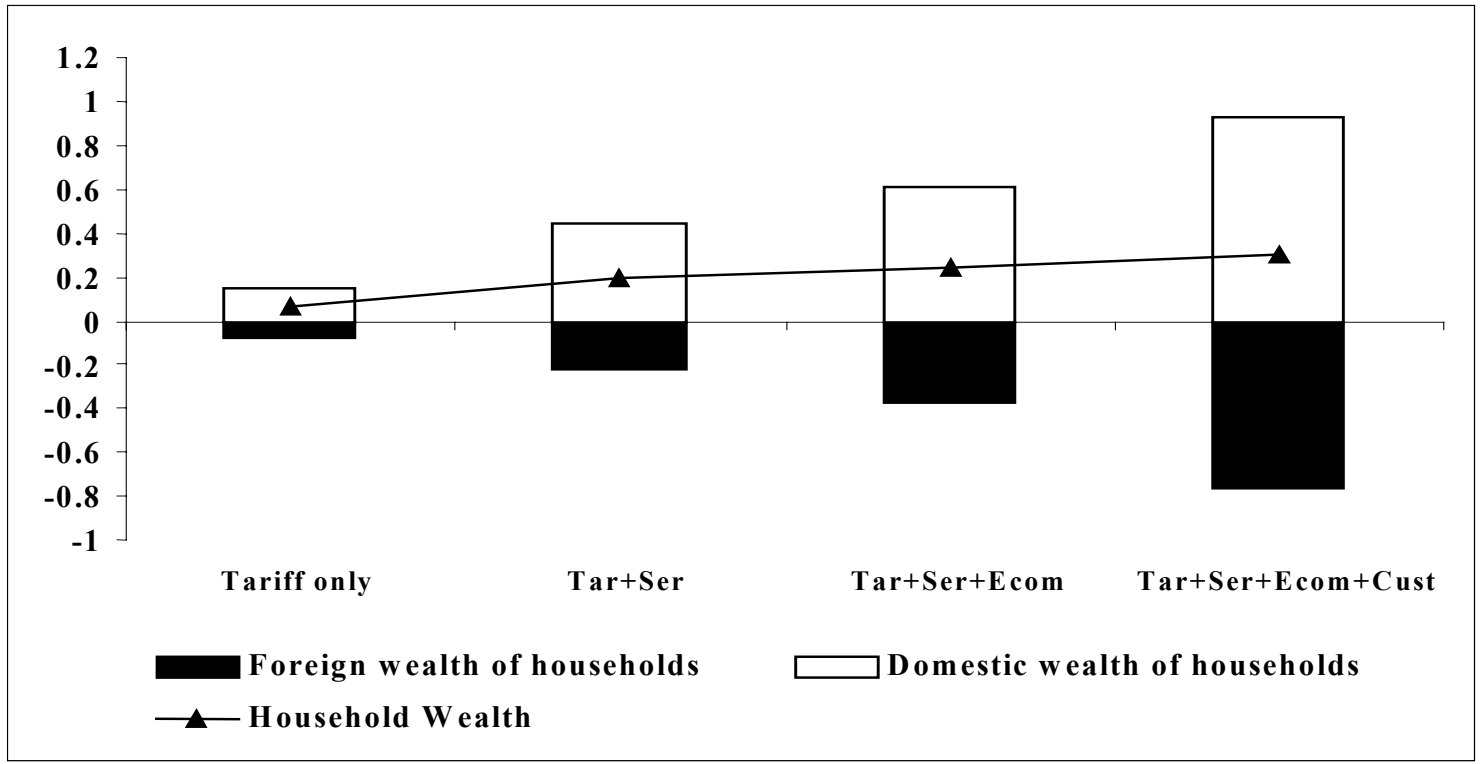

Figure 7. Effect of Japan-Singapore Free Trade Agreement on the Rate of Return in Japan

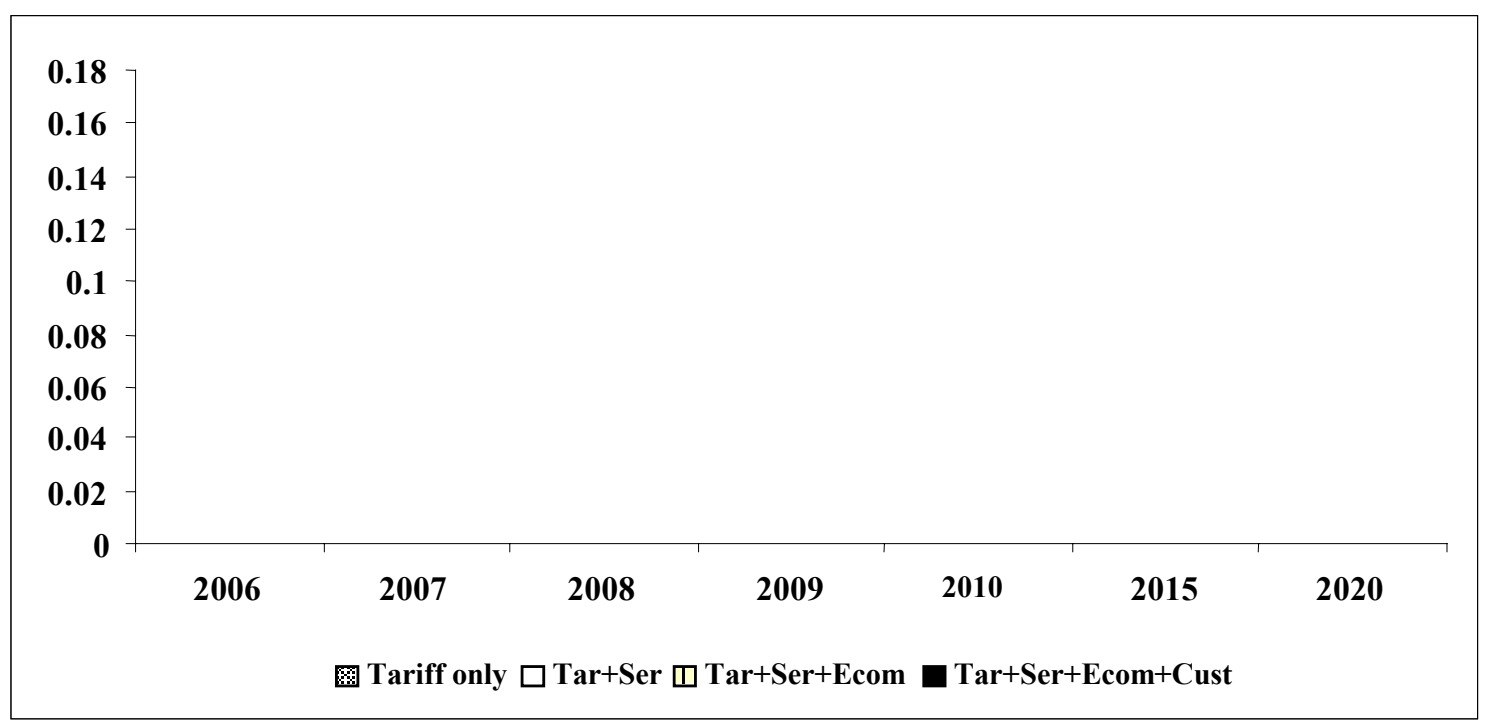

${ }^{1}$ Unlike the previous graph this shows the total (not the additional) cumulative $\%$ difference between the base case and the policy resulting from the simulation. Thus by adding customs automization ( Tar $+\mathrm{Ser}+\mathrm{Ecom}+$ Cust) benefits are positive overall and higher when compared with the e-commerce simulation (Tar $+\mathrm{Ser}+$ Ecom). This is shown by the larger positive numbers under Tar $+\mathrm{Ser}+\mathrm{Ecom}+\mathrm{Cust}$ than under Tar $+\mathrm{Ser}+$ Ecom. 
Figure 8. Effect of Japan-Singapore Free Trade Agreement on Japan's Trade Balance

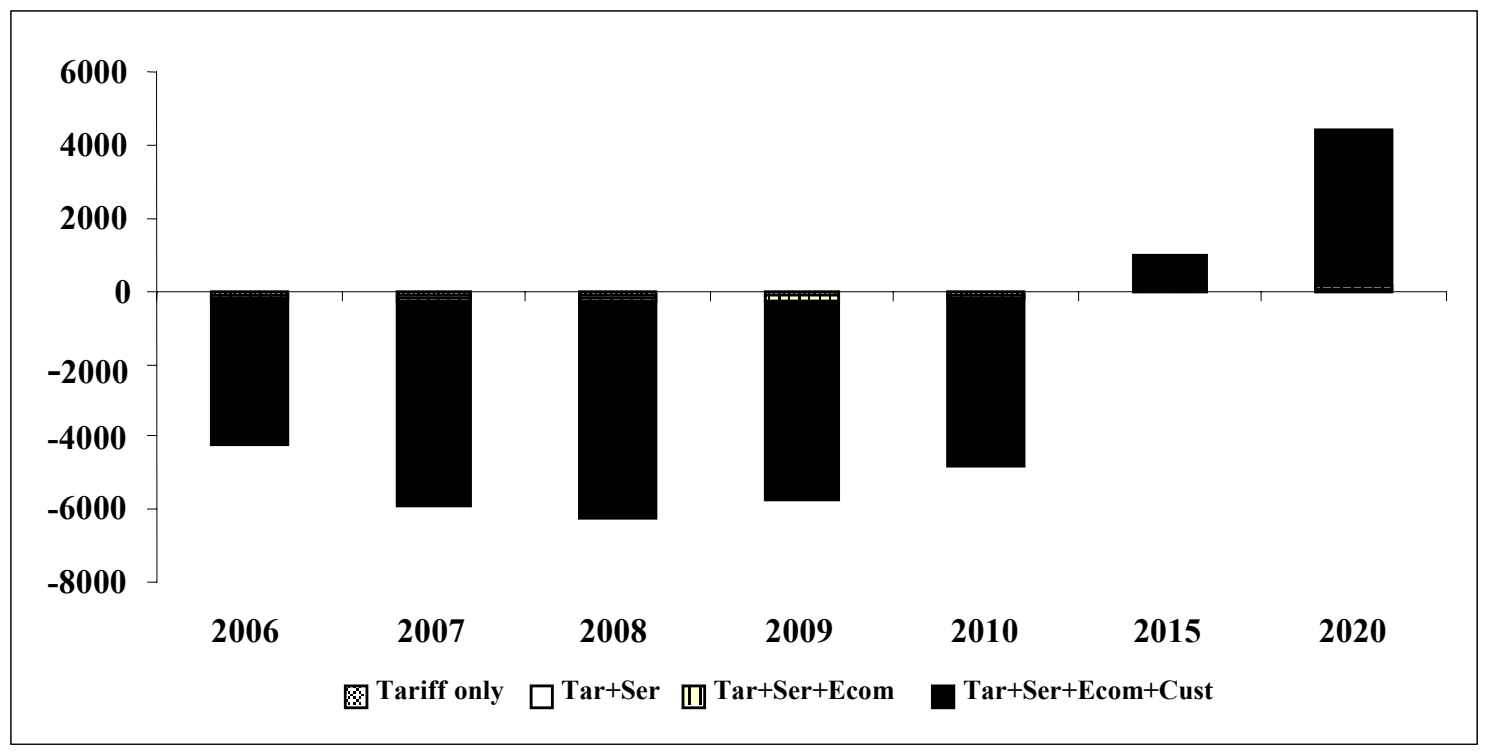


Table 1. Bilateral Tariffs and Composition of Imports

(Post-Uruguay Round, ad valorem tariff and projected share of total imports, 2005)

\begin{tabular}{|c|c|c|c|c|}
\hline \multirow[b]{2}{*}{ Commodity } & \multicolumn{2}{|c|}{ Imports from Japan } & \multicolumn{2}{|c|}{ Imports from Singapore } \\
\hline & Trade share & Tariff rate & Trade share & Tariff rate \\
\hline & \multicolumn{2}{|c|}{ (percent) } & \multicolumn{2}{|c|}{ (percent) } \\
\hline rice & 0.0 & 0.0 & n.t. & n.t. \\
\hline othgrains & 0.0 & 0.0 & n.t. & n.t. \\
\hline othcrops & 0.1 & 0.0 & 0.5 & 1.8 \\
\hline meat & 0.0 & 0.0 & 0.1 & 47.7 \\
\hline othfood & 0.6 & 1.7 & 1.8 & 21.3 \\
\hline fish & 0.1 & 0.0 & 0.1 & 1.3 \\
\hline texwap & 0.6 & 0.0 & 0.2 & 6.6 \\
\hline leather & 0.0 & 0.0 & 0.1 & 6.1 \\
\hline extract & 7.4 & 0.0 & 1.0 & 0.2 \\
\hline pchemineral & 8.2 & 0.0 & 6.6 & 1.2 \\
\hline omnfcs & 5.9 & 0.0 & 2.7 & 0.1 \\
\hline autos & 4.5 & 0.0 & 0.02 & 0.0 \\
\hline machequip & 59.5 & 0.0 & 32.8 & 0.1 \\
\hline utilities & 0.1 & 0.0 & 0.1 & 0.0 \\
\hline construction & 0.0 & 0.0 & 0.0 & 0.0 \\
\hline tradetrans & 1.3 & 0.0 & 48.9 & 0.0 \\
\hline busfinance & 11.7 & 0.0 & 5.1 & 0.0 \\
\hline Total (million \$US) & $\$ 33,731$ & & $\$ 18,066$ & \\
\hline
\end{tabular}

Table 2. Time Saving per Day and Price Reduction by Customs Automization (percent ad valorem)

\begin{tabular}{lccccc}
\hline \multirow{2}{*}{$\begin{array}{l}\text { Opportunity cost of } \\
\text { a day in trade }\end{array}$} & & \multicolumn{2}{c}{ No linking effect } & \multicolumn{2}{c}{ With linking effect } \\
\cline { 2 - 5 } & & $\begin{array}{c}\text { Exports } \\
(\boldsymbol{a})\end{array}$ & $\begin{array}{c}\text { Imports } \\
\text { (b) }\end{array}$ & $\begin{array}{c}\text { Exports } \\
(\boldsymbol{c})\end{array}$ & $\begin{array}{c}\text { Imports } \\
\text { (d) }\end{array}$ \\
\hline rice & 0 & 0.201 & 0.203 & 0.214 & 0.268 \\
othgrains & 0 & 0.201 & 0.203 & 0.214 & 0.268 \\
othcrops & 0 & 0.201 & 0.203 & 0.214 & 0.268 \\
meat & 0 & 0.201 & 0.203 & 0.214 & 0.268 \\
othfood & 0 & 0.201 & 0.203 & 0.214 & 0.268 \\
fish & 0.14 & 0.431 & 0.406 & 0.619 & 0.741 \\
texwap & 0.14 & 0.435 & 0.409 & 0.627 & 0.749 \\
leather & 0.13 & 0.422 & 0.398 & 0.604 & 0.723 \\
extract & 0.30 & 0.707 & 0.649 & 1.107 & 1.309 \\
pchemineral & 0.94 & 1.795 & 1.609 & 3.027 & 3.549 \\
omnfcs & 0.29 & 0.686 & 0.631 & 1.069 & 1.266 \\
autos & 0.16 & 0.465 & 0.436 & 0.679 & 0.811 \\
machequip & 0.51 & 1.072 & 0.971 & 1.750 & 2.061 \\
\hline
\end{tabular}

(percent ad valorem) 
Table 3. Reductions in Bilateral Prices due to Customs Automization

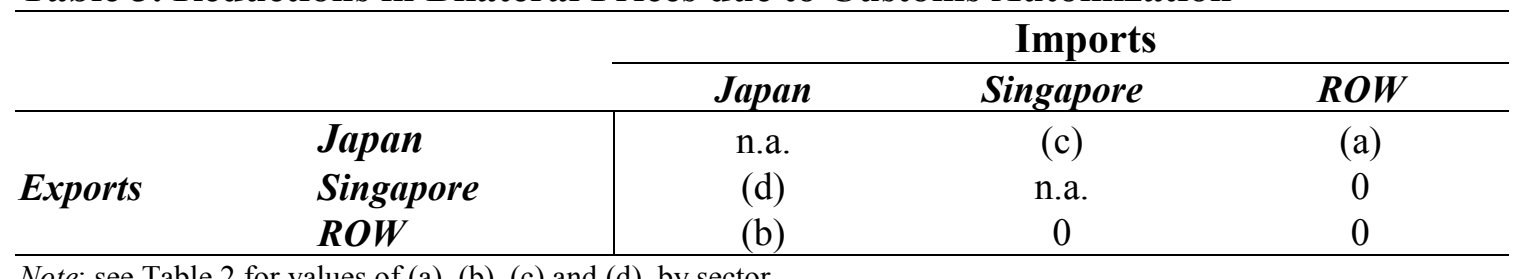

Note: see Table 2 for values of (a), (b), (c) and (d), by sector.

Table 4. Reduction in Price due to E-commerce

\begin{tabular}{lcc}
\hline & $\begin{array}{c}\text { E-commerce } \\
\text { penetration rate }\end{array}$ & $\begin{array}{c}\text { Potential reduction } \\
\text { in average price (\%) }\end{array}$ \\
rice & 0.95 & 0.09 \\
othgrains & 0.95 & 0.09 \\
othcrops & 0.95 & 0.09 \\
meat & 0.95 & 0.09 \\
othfood & 0.95 & 0.09 \\
fish & 0.95 & 0.09 \\
texwap & 2.80 & 0.27 \\
leather & 2.80 & 0.27 \\
extract & 0.82 & 0.08 \\
pchemineral & 0.20 & 0.02 \\
omnfcs & 0.80 & 0.08 \\
autos & 14.20 & 1.39 \\
machequip & 6.59 & 0.65 \\
utilities & 0.10 & 0.01 \\
construction & 0.04 & 0.00 \\
tradetrans & 0.20 & 0.02 \\
busfinance & 0.20 & 0.02 \\
\hline
\end{tabular}

Note: Price reduction $=$ e-commerce penetration rate

* reduction in margin as $\%$ of final price.

Source: Authors' computation based on estimates from MRI. 
Table 5. Estimated Tariff Equivalents for Services

(percent ad valorem)

\begin{tabular}{lcc}
\hline Regions & Business Services & Construction \\
\hline North America & 9.0 & 9.9 \\
Western Europe & 9.4 & 18.5 \\
Australia and New Zealand & 7.2 & 24.5 \\
Japan & 20.6 & 29.9 \\
China & 19.5 & 41.1 \\
Taiwan & 7.1 & 28.5 \\
Korea & 8.1 & 28.8 \\
Indonesia & 6.9 & 9.6 \\
Other South East Asia & 5.2 & 17.8 \\
India & 13.5 & 61.7 \\
Brazil & 36.8 & 57.5 \\
Other Latin America & 5.6 & 26.3 \\
Other Middle East and North Africa & 4.4 & 9.6 \\
CEECs and Russia & 19.1 & 52.1 \\
South Africa & 15.4 & 41.9 \\
Other Sub-Saharan Africa & 0.4 & 11.1 \\
Rest of World & 19.2 & 29.1 \\
\hline Soure: Fras (199) and
\end{tabular}

Source: Francois (1999) and author's estimation

Table 6. Baseline Policies

\begin{tabular}{lll}
\hline \multicolumn{1}{c}{ Imports } & \multicolumn{1}{c}{ Exports } \\
\hline $1995-2000$ & $\begin{array}{l}\text { 1. UR tariff reductions for all regions } \\
\text { except China and Taiwan (no shocks } \\
\text { to agriculture) }\end{array}$ & $\begin{array}{l}\text { USA and EU quotas increased on } \\
\text { exports of textiles and wearing apparel } \\
\text { for all regions except Taiwan and } \\
\text { 2. Singapore reduces tariffs to zero } \\
\text { on all commodities except beverages } \\
\text { and tobacco. }\end{array}$ \\
& $\begin{array}{l}\text { China. } \\
\text { 3. Pre-WTO tariff reductions }\end{array}$ \\
& $\begin{array}{l}\text { undertaken by China prior to 2000. } \\
\text { UR tariff reductions for all regions. }\end{array}$ & \\
& $\begin{array}{l}\text { China and Taiwan's WTO agreement } \\
\text { included (no shocks to agriculture, } \\
\text { except for China and Taiwan). }\end{array}$ & $\begin{array}{l}\text { exports of textiles and wearing apparel } \\
\text { for all regions including Taiwan and } \\
\text { China). }\end{array}$ \\
& & None \\
\hline
\end{tabular}


Table 7. Effect of Japan-Singapore Free Trade Agreement on Capital, Real GDP, Exports and Imports and Equity Ownership in 2020

(cumulative percent differences from baseline simulation)

\begin{tabular}{lccccccc}
\hline & $\begin{array}{c}\text { Capital } \\
\text { Stocks }\end{array}$ & $\begin{array}{c}\text { Real } \\
\text { GDP }\end{array}$ & $\begin{array}{c}\text { Real } \\
\text { Exports }\end{array}$ & $\begin{array}{c}\text { Real } \\
\text { Imports }\end{array}$ & Wealth & $\begin{array}{c}\text { Overseas } \\
\text { Holdings }\end{array}$ & $\begin{array}{c}\text { Equity held } \\
\text { by foreigners }\end{array}$ \\
\hline Singapore & 1.81 & 1.67 & 1.00 & 0.64 & 0.31 & -0.77 & 2.66 \\
Japan & 0.33 & 0.20 & 1.93 & 1.82 & 0.34 & -0.27 & 1.45 \\
Korea & 0.10 & 0.11 & 0.08 & -0.05 & -0.03 & -0.08 & 0.06 \\
Malaysia & 0.27 & 0.31 & 0.15 & 0.01 & 0.00 & -0.10 & 0.37 \\
Thailand & 0.32 & 0.33 & 0.30 & 0.11 & -0.04 & -1.53 & 1.72 \\
IndPhlViet & 0.17 & 0.13 & 0.09 & 0.00 & -0.01 & -0.18 & 0.33 \\
China & -0.01 & 0.04 & 0.10 & 0.00 & -0.04 & 0.20 & -0.40 \\
Hongkong & 0.23 & 0.27 & 0.08 & 0.01 & -0.26 & -0.66 & 0.15 \\
Taiwan & 0.20 & 0.18 & 0.10 & -0.08 & -0.05 & -0.16 & 0.21 \\
SoAsia & -0.02 & 0.01 & -0.02 & -0.04 & -0.06 & 0.07 & -0.19 \\
AusNZL & 0.02 & 0.03 & 0.01 & -0.02 & -0.04 & -0.06 & -0.02 \\
Canada & -0.04 & -0.01 & -0.07 & -0.07 & -0.06 & 0.07 & -0.24 \\
USA & -0.03 & 0.01 & -0.03 & -0.01 & -0.07 & 0.08 & -0.25 \\
Mexico & -0.02 & 0.00 & -0.08 & -0.10 & -0.08 & 0.10 & -0.28 \\
Chile & 0.03 & 0.03 & 0.03 & -0.01 & -0.04 & -0.06 & -0.01 \\
WEurope & -0.07 & -0.01 & -0.09 & -0.04 & -0.06 & 0.01 & -0.19 \\
Remainder & -0.05 & -0.01 & -0.04 & -0.02 & -0.05 & 0.06 & -0.17 \\
\hline
\end{tabular}

Source: Authors' simulation. 
Table 8. Effect of Japan-Singapore Free Trade Agreement on Imports in 2020 (import volume change in millions of US\$, percent change in parentheses)

\begin{tabular}{|c|c|c|c|c|c|c|c|}
\hline & \multicolumn{2}{|c|}{ Japan's imports from } & \multicolumn{2}{|c|}{ Singapore's imports from } & \multicolumn{3}{|c|}{ ROW's imports from } \\
\hline & Singapore & ROW & Japan & ROW & Japan & Singapore & ROW \\
\hline \multirow[t]{2}{*}{ rice } & n.t. & 0.06 & 0.0 & 10.5 & -0.4 & 0.0 & -2.0 \\
\hline & & $(1.12)$ & $(1.72)$ & $(2.04)$ & $(-0.77)$ & $(0.12)$ & $(-0.02)$ \\
\hline \multirow[t]{2}{*}{ othgrains } & n.t. & -5.3 & 0.0 & 2.3 & -0.1 & 0.0 & 17.8 \\
\hline & & $(-0.09)$ & $(0.78)$ & $(1.11)$ & $(-0.75)$ & $(0.08)$ & $(0.02)$ \\
\hline \multirow[t]{2}{*}{ othcrops } & 10.8 & 75.2 & 0.4 & 40.9 & -7.5 & -37.3 & 120.0 \\
\hline & $(7.88)$ & $(0.45)$ & $(0.44)$ & $(0.74)$ & $(-0.78)$ & $(-1.05)$ & $(0.05)$ \\
\hline \multirow[t]{2}{*}{ meat } & 95.7 & 46.5 & 0.3 & 40.8 & -2.6 & -26.9 & 166.3 \\
\hline & $(417.74)$ & $(0.27)$ & $(1.90)$ & $(1.89)$ & $(-0.41)$ & $(-1.94)$ & $(0.14)$ \\
\hline \multirow[t]{2}{*}{ othfood } & 688.2 & 42.7 & 29.2 & 151.6 & -22.5 & 12.6 & 758.8 \\
\hline & ( 124.82$)$ & $(0.11)$ & $(9.08)$ & $(1.81)$ & $(-0.64)$ & $(0.13)$ & $(0.20)$ \\
\hline \multirow[t]{2}{*}{ fish } & 2.2 & 27.3 & 1.0 & 1.7 & 6.8 & -2.1 & 13.0 \\
\hline & $(10.58)$ & $(1.38)$ & $(2.46)$ & $(0.86)$ & $(0.61)$ & $(-0.68)$ & $(0.07)$ \\
\hline \multirow[t]{2}{*}{ texwap } & 38.1 & 1001.9 & 8.9 & 81.9 & -4.4 & -38.7 & 216.1 \\
\hline & $(58.89)$ & $(1.71)$ & $(3.35)$ & $(0.89)$ & $(-0.04)$ & $(-0.74)$ & $(0.04)$ \\
\hline \multirow[t]{2}{*}{ leather } & 54.4 & 295.8 & 0.8 & 31.2 & 4.7 & 0.2 & 101.0 \\
\hline & $(79.58)$ & $(1.57)$ & $(5.81)$ & $(1.32)$ & $(0.92)$ & $(0.02)$ & $(0.06)$ \\
\hline \multirow[t]{2}{*}{ extract } & 21.7 & 1672.0 & 164.8 & 336.7 & 723.8 & 13.5 & -1595.5 \\
\hline & $(6.25)$ & $(1.24)$ & $(3.85)$ & $(0.61)$ & ( 1.12$)$ & $(0.08)$ & $(-0.10)$ \\
\hline \multirow[t]{2}{*}{ pchemineral } & 294.8 & 1167.9 & 400.5 & 341.0 & 3417.3 & -159.5 & -3219.4 \\
\hline & $(14.40)$ & $(1.83)$ & ( 7.91$)$ & $(0.68)$ & ( 3.63 ) & $(-0.27)$ & $(-0.22)$ \\
\hline \multirow[t]{2}{*}{ omnfes } & 48.1 & 950.8 & 95.5 & 219.8 & 235.3 & -3.0 & -213.6 \\
\hline & $(4.87)$ & $(1.59)$ & $(2.98)$ & $(0.82)$ & $(0.78)$ & $(-0.01)$ & $(-0.03)$ \\
\hline \multirow[t]{2}{*}{ autos } & 1.9 & 745.0 & 284.6 & 66.5 & 342.3 & 92.8 & -760.3 \\
\hline & ( 23.99$)$ & $(2.83)$ & $(12.60)$ & $(1.08)$ & $(0.42)$ & ( 1.97 ) & $(-0.10)$ \\
\hline \multirow[t]{2}{*}{ machequip } & 1513.6 & 3839.4 & 2905.3 & 1610.7 & 9509.3 & 747.5 & -10050.2 \\
\hline & $(13.45)$ & $(2.72)$ & ( 9.12 ) & $(0.72)$ & $(2.49)$ & $(0.31)$ & $(-0.33)$ \\
\hline \multirow[t]{2}{*}{ utilities } & 0.2 & 16.3 & -0.2 & 30.8 & -14.8 & -12.4 & 35.9 \\
\hline & $(0.91)$ & $(1.19)$ & $(-1.10)$ & $(0.78)$ & $(-1.86)$ & $(-0.27)$ & $(0.01)$ \\
\hline \multirow[t]{2}{*}{ construction } & 0.2 & 0.5 & 0.0 & 0.4 & -0.1 & 0.3 & 26.4 \\
\hline & ( 110.04$)$ & $(0.65)$ & $(-0.84)$ & $(0.77)$ & $(-1.53)$ & $(0.29)$ & $(0.04)$ \\
\hline \multirow[t]{2}{*}{ tradetrans } & 160.7 & 1395.3 & -5.0 & 55.6 & -656.3 & 23.0 & 647.8 \\
\hline & $(0.87)$ & $(0.85)$ & $(-0.82)$ & $(0.85)$ & $(-1.06)$ & $(0.05)$ & $(0.07)$ \\
\hline \multirow[t]{2}{*}{ busfinance } & 1300.1 & -386.3 & 5.7 & 558.9 & -377.8 & -14.5 & 1608.7 \\
\hline & $(67.57)$ & $(-0.73)$ & $(0.09)$ & $(1.64)$ & $(-1.46)$ & $(-0.13)$ & $(0.27)$ \\
\hline
\end{tabular}

Source: Authors' simulation. 
Table 9. Effect of Japan-Singapore Free Trade Agreement on Outputs in 2020 (volume change in millions of US\$, percent change in parentheses)

\begin{tabular}{|c|c|c|c|c|c|c|c|c|}
\hline & \multicolumn{4}{|c|}{ Japan } & \multicolumn{4}{|c|}{ Singapore } \\
\hline & $\operatorname{sim} 1$ & $\operatorname{sim} 2$ & $\operatorname{sim} 3$ & $\operatorname{sim} 4$ & $\operatorname{sim} 1$ & $\operatorname{sim} 2$ & $\operatorname{sim} 3$ & $\operatorname{sim} 4$ \\
\hline \multirow[t]{2}{*}{ rice } & -8.0 & -6.0 & -6.5 & -2.1 & 0.1 & 0.1 & 0.1 & 0.1 \\
\hline & $(-0.01)$ & $(-0.01)$ & $(-0.01)$ & $(-0.00)$ & $(0.50)$ & $(0.46)$ & $(0.56)$ & $(0.95)$ \\
\hline \multirow[t]{2}{*}{ othgrains } & -0.3 & -0.1 & -0.6 & -18.6 & 0.0 & 0.0 & 0.0 & 0.1 \\
\hline & $(-0.02)$ & $(-0.01)$ & $(-0.03)$ & $(-1.02)$ & $(0.59)$ & $(0.54)$ & $(0.66)$ & ( 1.05$)$ \\
\hline \multirow[t]{2}{*}{ othcrops } & -4.3 & -3.1 & -4.3 & -35.3 & -9.8 & -10.9 & -11.4 & -12.3 \\
\hline & $(-0.01)$ & $(-0.01)$ & $(-0.01)$ & $(-0.09)$ & $(-0.50)$ & $(-0.55)$ & $(-0.58)$ & $(-0.63)$ \\
\hline \multirow[t]{2}{*}{ meat } & -33.8 & -26.4 & -32.5 & -204.8 & 46.4 & 44.1 & 44.3 & 45.7 \\
\hline & $(-0.03)$ & $(-0.02)$ & $(-0.03)$ & $(-0.16)$ & $(2.20)$ & ( 2.09$)$ & $(2.10)$ & $(2.16)$ \\
\hline \multirow[t]{2}{*}{ othfood } & -192.3 & -169.4 & -175.7 & -234.6 & 590.3 & 575.9 & 586.5 & 635.4 \\
\hline & $(-0.04)$ & $(-0.03)$ & $(-0.03)$ & $(-0.04)$ & $(4.80)$ & ( 4.69 ) & ( 4.77 ) & ( 5.17$)$ \\
\hline \multirow[t]{2}{*}{ fish } & -6.8 & -5.4 & -6.2 & -21.6 & 0.0 & 0.0 & 0.1 & 0.2 \\
\hline & $(-0.02)$ & $(-0.02)$ & $(-0.02)$ & $(-0.06)$ & $(0.02)$ & $(0.01)$ & $(0.02)$ & $(0.06)$ \\
\hline \multirow[t]{2}{*}{ texwap } & 6.0 & 23.8 & -0.2 & -745.7 & 19.9 & 3.0 & 2.3 & 3.5 \\
\hline & $(0.00)$ & $(0.01)$ & $(-0.00)$ & $(-0.36)$ & $(0.36)$ & $(0.05)$ & $(0.04)$ & $(0.06)$ \\
\hline \multirow[t]{2}{*}{ leather } & -0.5 & 2.6 & -1.3 & -161.5 & 36.5 & 34.8 & 37.4 & 45.5 \\
\hline & $(-0.00)$ & $(0.01)$ & $(-0.01)$ & $(-0.74)$ & ( 4.11$)$ & (3.92) & $(4.20)$ & ( 5.12$)$ \\
\hline \multirow[t]{2}{*}{ extract } & 49.5 & 127.5 & 130.6 & 458.5 & 46.2 & 16.2 & 66.0 & 173.1 \\
\hline & $(0.01)$ & $(0.02)$ & $(0.03)$ & $(0.09)$ & $(0.17)$ & $(0.06)$ & $(0.25)$ & $(0.65)$ \\
\hline \multirow[t]{2}{*}{ pchemineral } & -9.2 & 67.9 & 60.8 & 2242.2 & 111.7 & 93.4 & 147.2 & 203.2 \\
\hline & $(-0.00)$ & $(0.01)$ & $(0.01)$ & $(0.27)$ & $(0.17)$ & $(0.14)$ & $(0.22)$ & $(0.31)$ \\
\hline \multirow[t]{2}{*}{ omnfes } & 10.5 & 38.1 & 32.6 & 163.6 & 7.1 & -18.1 & 8.1 & 108.5 \\
\hline & $(0.00)$ & $(0.01)$ & $(0.01)$ & $(0.03)$ & $(0.03)$ & $(-0.07)$ & $(0.03)$ & $(0.40)$ \\
\hline \multirow[t]{2}{*}{ autos } & 38.2 & 82.1 & 146.5 & 312.6 & -3.9 & -10.9 & 38.0 & 86.4 \\
\hline & $(0.02)$ & $(0.04)$ & $(0.07)$ & $(0.16)$ & $(-0.05)$ & $(-0.13)$ & $(0.47)$ & ( 1.07$)$ \\
\hline \multirow[t]{2}{*}{ machequip } & 101.8 & 295.6 & 527.4 & 6054.3 & -78.1 & -381.9 & 540.9 & 2029.3 \\
\hline & $(0.01)$ & $(0.03)$ & $(0.05)$ & $(0.63)$ & $(-0.03)$ & $(-0.16)$ & $(0.23)$ & $(0.86)$ \\
\hline \multirow[t]{2}{*}{ utilities } & -7.1 & 6.9 & 12.7 & 355.2 & 15.7 & 37.3 & 60.4 & 131.0 \\
\hline & $(-0.00)$ & $(0.00)$ & $(0.00)$ & $(0.09)$ & $(0.07)$ & $(0.16)$ & $(0.26)$ & $(0.56)$ \\
\hline \multirow[t]{2}{*}{ construction } & -14.7 & 17.4 & 98.6 & 2777.5 & 55.1 & 188.2 & 246.9 & 455.7 \\
\hline & $(-0.00)$ & $(0.00)$ & $(0.01)$ & $(0.30)$ & $(0.14)$ & $(0.46)$ & $(0.61)$ & ( 1.12$)$ \\
\hline \multirow[t]{2}{*}{ tradetrans } & 6.3 & 85.4 & 87.5 & 716.8 & 8.3 & -23.6 & 98.5 & 491.7 \\
\hline & $(0.00)$ & $(0.01)$ & $(0.01)$ & $(0.06)$ & $(0.01)$ & $(-0.02)$ & $(0.10)$ & $(0.50)$ \\
\hline \multirow[t]{2}{*}{ busfinance } & -5.5 & -186.8 & -155.5 & 1124.3 & 29.6 & 1155.2 & 1234.8 & 1484.5 \\
\hline & $(-0.00)$ & $(-0.02)$ & $(-0.01)$ & $(0.10)$ & $(0.05)$ & $(2.11)$ & $(2.26)$ & $(2.71)$ \\
\hline
\end{tabular}

Note: sim1-4 differ in components of the simulation as follows, sim1 Tariff only sim2 Tariff and Service

sim3 Tariff, Service and E-commerce sim4 Tariff, Service, E-commerce and Customs Automization Source: Authors' simulation. 
Table 10. Welfare Effects of FTA: Equivalent Variation in 2020 in millions of US\$

\begin{tabular}{lcccccc} 
& Tariffs & Services & E-commerce & $\begin{array}{c}\text { Customs } \\
\text { Automization }\end{array}$ & Full FTA & $\begin{array}{c}\text { Full FTA } \\
\text { (\% Change } \\
\text { in Welfare }\end{array}$ \\
\hline Japan & -85.0 & 236.7 & 170.6 & 6597.5 & 6919.7 & 0.157 \\
Korea & -4.9 & -6.0 & -10.6 & 258.6 & 237.1 & 0.059 \\
Singapore & 55.0 & 115.3 & 55.5 & 171.0 & 396.8 & 0.668 \\
Malaysia & 2.6 & -4.0 & 1.1 & 135.9 & 135.6 & 0.161 \\
Thailand & -1.8 & 0.3 & -15.7 & 263.6 & 246.3 & 0.170 \\
IndPhlViet & -1.9 & -8.1 & 1.9 & 232.8 & 224.7 & 0.089 \\
China & -4.1 & -5.9 & -12.3 & 288.4 & 266.1 & 0.041 \\
Hongkong & -0.2 & -2.6 & 3.5 & 79.3 & 80.1 & 0.092 \\
Taiwan & -2.3 & -2.1 & -3.3 & 207.1 & 199.5 & 0.079 \\
SoAsia & -2.7 & -3.2 & 0.6 & 45.0 & 39.7 & 0.010 \\
AusNZL & -1.7 & -4.1 & 1.4 & 70.2 & 65.8 & 0.019 \\
Canada & -2.4 & -5.9 & 0.6 & 20.4 & 12.7 & 0.003 \\
USA & -20.2 & -33.8 & -11.0 & 588.2 & 523.1 & 0.008 \\
Mexico & -0.6 & -1.0 & -0.9 & 7.9 & 5.5 & 0.002 \\
Chile & -1.4 & -2.7 & 0.3 & 15.4 & 11.7 & 0.021 \\
WEurope & -21.2 & -39.2 & -21.2 & 212.9 & 131.3 & 0.002 \\
Remainder & -12.5 & -27.5 & 6.8 & 36.8 & 3.6 & 0.000 \\
World & -105.3 & 206.1 & 167.3 & 9231.2 & 9499.2 & \\
\hline Sorce: Ant & & & & & & \\
\hline
\end{tabular}


Appendix 1. Aggregation of GTAP Data Base

\section{Appendix Table A1: Sector Aggregation}

Aggregation of GTAP Database from GTAP(v.4) Full Scale Data ( 50 sectors)

\begin{tabular}{|c|c|c|}
\hline 50 Sectors & GTAP code & This study \\
\hline 1 Paddy rice & $\mathrm{pdr}$ & rice \\
\hline 2 Wheat & wht & otherains \\
\hline 3 Cereal grains nec & gro & otherains \\
\hline 4 Vegetables. fruit. nuts & $\mathrm{v} f$ & othcrops \\
\hline 5 Oil seeds & osd & othcrops \\
\hline 6 Sugar cane. sugar beet & $\mathrm{c} b$ & othcrops \\
\hline 7 Plant-based fibers & $\mathrm{pfb}$ & othcrops \\
\hline 8 Crops nec & ocr & othcrops \\
\hline 9 Bovine cattle, sheep and goats, horses & ctl & meat \\
\hline 10 Animal products nec & oap & meat \\
\hline 11 Raw milk & rmk & othfood \\
\hline 12 Wool. silk-worm cocoons & wol & othcrops \\
\hline 13 Forestry & for & extract \\
\hline 14 Fishing & fsh & fish \\
\hline 15 Coal & col & extract \\
\hline 16 Oil & oil & extract \\
\hline 17 Gas & gas & extract \\
\hline 18 Minerals nec & omn & extract \\
\hline 19 Bovine cattle, sheep and goat, horse meat prods & $\mathrm{cmt}$ & meat \\
\hline 20 Meat products nec & omt & meat \\
\hline 21 Vegetable oils and fats & vol & othfood \\
\hline 22 Dairv products & mil & othfood \\
\hline 23 Processed rice & pcr & rice \\
\hline 24 Sugar & sgr & othfood \\
\hline 25 Food products nec & ofd & othfood \\
\hline 26 Beverages and tobacco products & $\mathrm{b} \mathrm{t}$ & othfood \\
\hline 27 Textiles & tex & texwap \\
\hline 28 Wearing apparel & wap & texwap \\
\hline 29 Leather products & lea & leather \\
\hline 30 Wood products & lum & omnfes \\
\hline 31 Paper products, publishing & ppp & omnfes \\
\hline 32 Petroleum. coal products & $\mathrm{pc}$ & pchemineral \\
\hline 33 Chemical, rubber, plastic products & crp & pchemineral \\
\hline 34 Mineral products nec & $\mathrm{nmm}$ & pchemineral \\
\hline 35 Ferrous metals & i s & extract \\
\hline 36 Metals nec & $\mathrm{nfm}$ & extract \\
\hline 37 Metal products & fmp & extract \\
\hline 38 Motor vehicles and parts & mvh & autos \\
\hline 39 Transport equipment nec & otn & machequip \\
\hline 40 Electronic equipment & ele & macheauip \\
\hline 41 Machinery and equipment nec & ome & machequip \\
\hline 42 Manufactures nec & omf & omnfes \\
\hline 43 Electricity & ely & utilities \\
\hline 44 Gas manufacture. distribution & gdt & utilities \\
\hline 45 Water & wtr & utilities \\
\hline 46 Construction & cns & construction \\
\hline 47 Trade, transport & $\mathrm{t} \mathrm{t}$ & tradetrans \\
\hline 48 Financial. business, recreational services & osp & busfinance \\
\hline 49 Public admin and defence, education, health & osg & utilities \\
\hline 50 Dwellings & dwe & utilities \\
\hline
\end{tabular}




\begin{tabular}{|c|c|c|}
\hline \multicolumn{3}{|c|}{ Aggregation of GTAP Database from GTAP(v.4) Full Scale Data (45 regions) } \\
\hline 45 Regions & GTAP code & This studv \\
\hline 1 Australia & aus & AusNZL \\
\hline 2 New Zealand & nzl & AusNZL \\
\hline 3 Japan & ipn & Japan \\
\hline 4 Korea & kor & Korea \\
\hline 5 Indonesia & idn & Indphlviet \\
\hline 6 Malaysia & mys & Malaysia \\
\hline 7 Philippines & phl & Indphlviet \\
\hline 8 Singapore & sgp & Singapore \\
\hline 9Thailand & tha & Thailand \\
\hline 10 Viet Nam & vnm & Indphlviet \\
\hline 11 China & chn & China \\
\hline 12 Hong Kong & hkg & HongKong \\
\hline 13 Taiwan & twn & Taiwan \\
\hline 14 India & ind & SoAsia \\
\hline 15 Sri Lanka & lka & SoAsia \\
\hline 16 Rest of South Asia & ras & SoAsia \\
\hline 17 Canada & can & Canada \\
\hline 18 United States of America & usa & USA \\
\hline 19 Mexico & $\operatorname{mex}$ & Mexico \\
\hline 20 Central America and the Caribbean & cam & ROW \\
\hline 21 Venezuela & ven & ROW \\
\hline 22 Colombia & col & ROW \\
\hline 23 Rest of the Andean Pact & rap & ROW \\
\hline 24 Argentina & $\arg$ & ROW \\
\hline 25 Brazil & bra & ROW \\
\hline 26 Chile & chl & Chile \\
\hline 27 Uruguay & ury & ROW \\
\hline 28 Rest of South America & rsm & ROW \\
\hline 29 United Kingdom & gbr & WEurope \\
\hline 30 Germany & deu & WEurope \\
\hline 31 Denmark & dnk & WEurope \\
\hline 32 Sweden & swe & WEurope \\
\hline 33 Finland & fin & WEurope \\
\hline 34 Rest of European Union & reu & WEurope \\
\hline 35 EFTA & eft & WEurope \\
\hline 36 Central European Associates & cea & ROW \\
\hline 37 Former Soviet Union & fsu & ROW \\
\hline 38 Turkey & tur & ROW \\
\hline 39 Rest of Middle East & rme & ROW \\
\hline 40 Morocco & mar & ROW \\
\hline 41 Rest of North Africa & rnf & ROW \\
\hline 42 South African Customs Union & saf & ROW \\
\hline 43 Rest of southern Africa & rsa & ROW \\
\hline 44 Rest of sub-Saharan Africa & rss & ROW \\
\hline 45 Rest of World & row & ROW \\
\hline
\end{tabular}




\section{Appendix Table A2: Regional Aggregation}

\section{Appendix 2. Construction of the Baseline}

The baseline scenario should reflect as closely as possible the changes expected to occur, in the world economy, over the period of interest. The baseline scenario contains macroeconomic forecasts of each country. The baseline scenario used in this report is based on a baseline developed by Walmsley, Dimaranan and McDougall (2000) for the Dynamic GTAP model (Ianchovichina, 1998 and Ianchovichina, and McDougall, 2001). The aim here was to obtain yearly macroeconomic data/projections for 211 countries, over the period 1995 to 2020. The macroeconomic variables of interest included: real gross domestic product, gross investment, capital stocks, population, skilled and unskilled labor and total labor. Not all of the data could be collected and estimates had to be made. Once projections are obtained or estimated for all 211 countries and years (1995-2020), the projections are aggregated and growth rates calculated to obtain the macro shocks for the base case scenario. The following sections describe this process and show the final baseline scenario used in this report.

Projections were obtained for gross domestic product, gross domestic investment, population, labor force and skilled labor. The source of these projections and a description are given below:

- $\quad$ Gross domestic product, gross domestic investment and population data and projections were available for 133 countries/regions for the period 1992 to 2007 (projections 1998 to 2007). These projections were obtained by combining historical and forecast data provided by the World Bank (Global Economic Perspectives Data Base, 1999).

- $\quad$ Labor force projections in the form of number of male and female workers were available for 205 countries/regions. Projections were provided on a five yearly basis from 1990 to 2020. These projections were obtained from the World Bank. Before proceeding data on male and female workers were added together to obtain projections for the total labor force.

- $\quad$ Skilled labor projections were obtained from two sources.

- For the less developed countries projections of the share of secondary and tertiary educated labor as a proportion of the population were obtained for 71 developing countries. These were five yearly projections from 1990 to 2020. These projections were obtained from Ahuja and Filmer (1995).

- For the developed economies skilled labor projections were based on projected skilled labor shares for 12 developed/developing regions over the period 1994 to 2050. These were obtained from the CPB (1999).

In addition to projections, macro data for the base or initial year (1995) was also collected for all 211 standard countries. For GDP and population, data was obtained for each of the countries from either from the World Bank or from the CIA World Factbook. Other macro variables, including gross domestic investment and capital stocks, were either obtained directly from the World Bank or GDP shares were used to estimate their value. This base year data was used to scale data, fill in missing values and obtain capital stock projections.

Undoubtedly, the projections obtained from the various sources listed above will be incomplete and in some cases incompatible. Some processing is required to get them into a common format and ensure that there are values for all 211 countries and for all years of interest (1995-2000). The methods used, including extrapolation and using GDP shares to fill in missing countries, to obtain the complete projections data set are outlined in greater details in Walmsley, Dimaranan and McDougall (2000). 
Once estimates are obtained for the 211 countries over the period 1995 to 2020, these estimates are then aggregated to obtain the estimates of real GDP, investment, capital stocks, population, and skilled and unskilled labor for the 17 regions and 13 periods used in this paper. The yearly growth rates of for real GDP, investment, cap ital stocks, population, and skilled and unskilled labor for the 17 regions are depicted in Figures A.1-A.5. Note that in the baseline, the 2007 growth rates are extrapolated out to 2020 for GDP, investment, and population.

\section{Figure A.1 Growth in Real GDP}

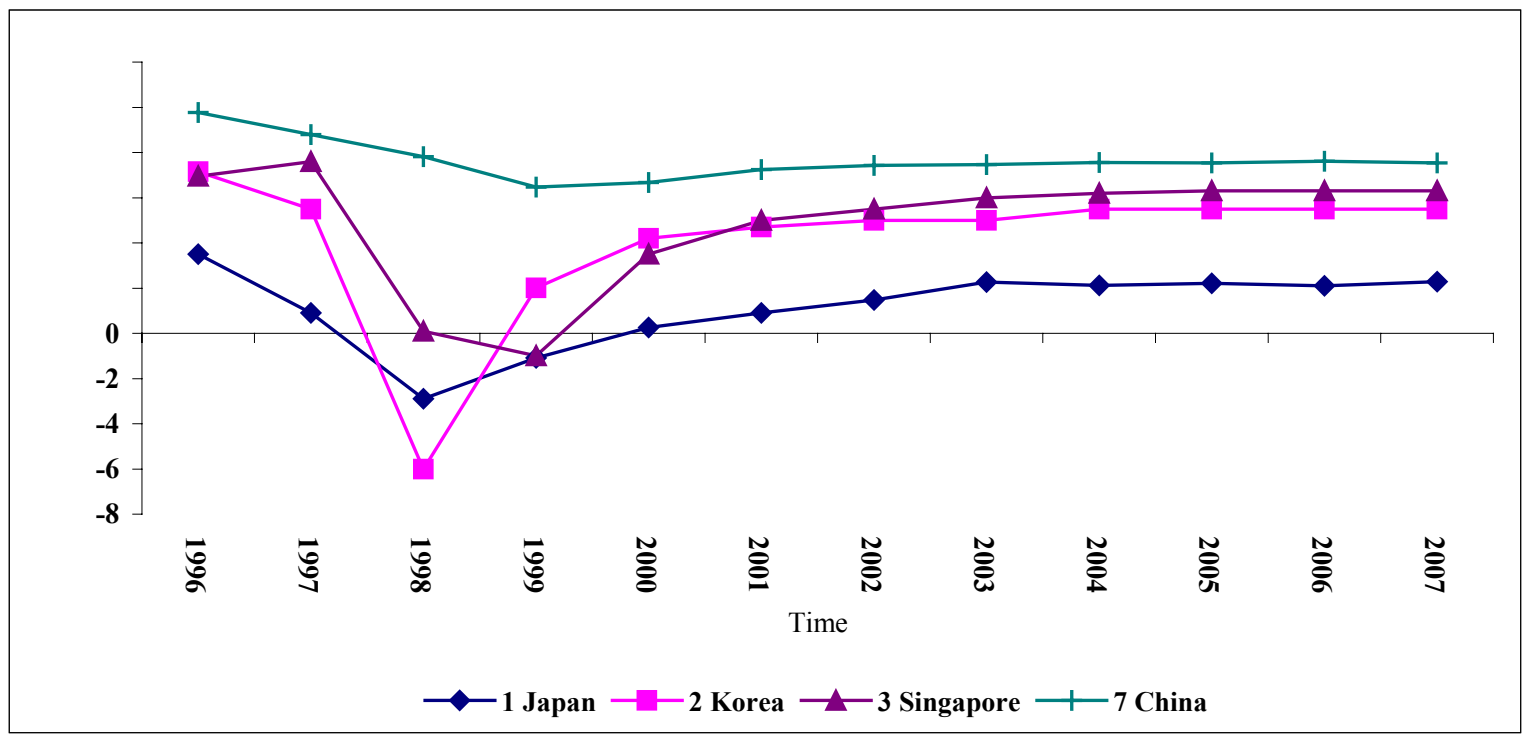

Figure A.2 Growth in Gross Investment

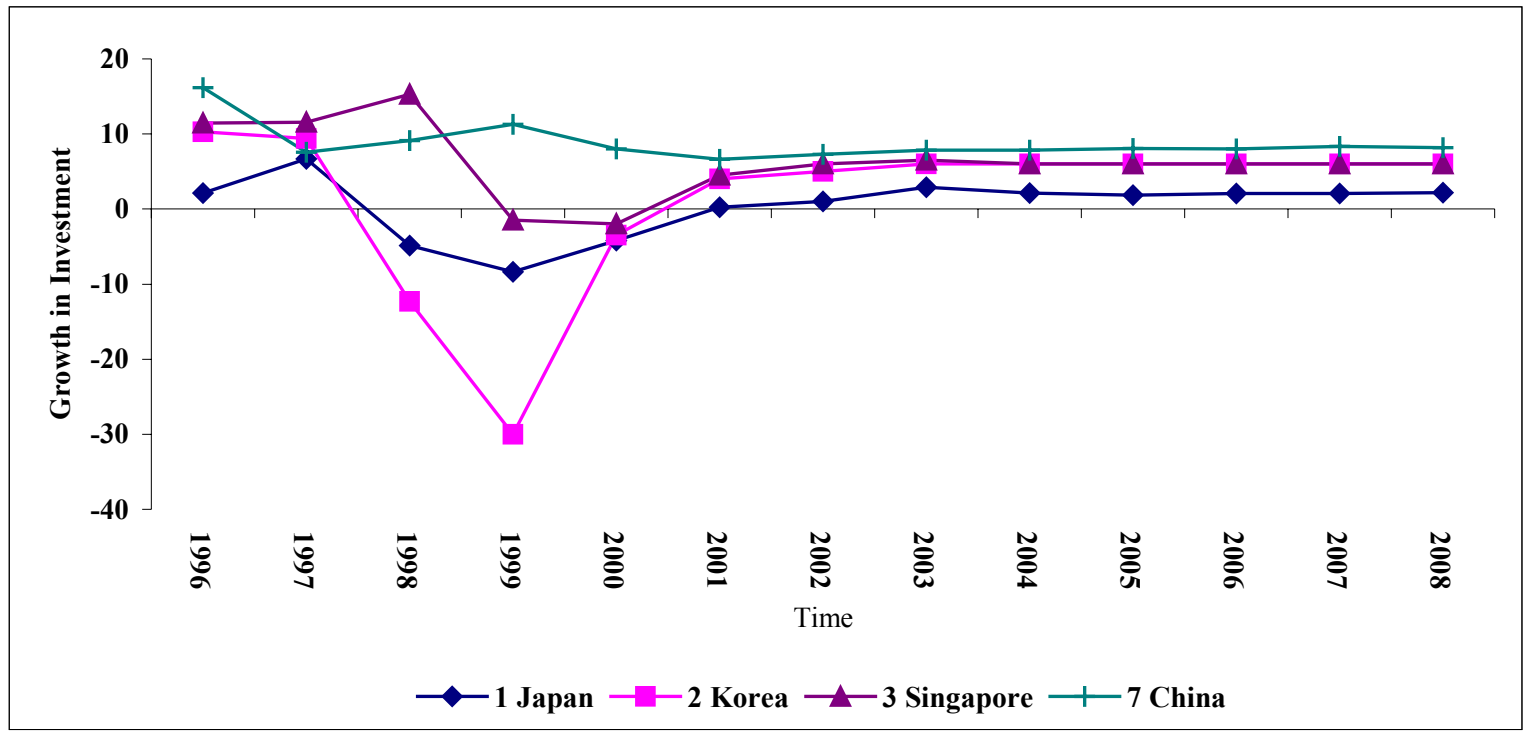


Figure A.3 Growth in Capital Stocks

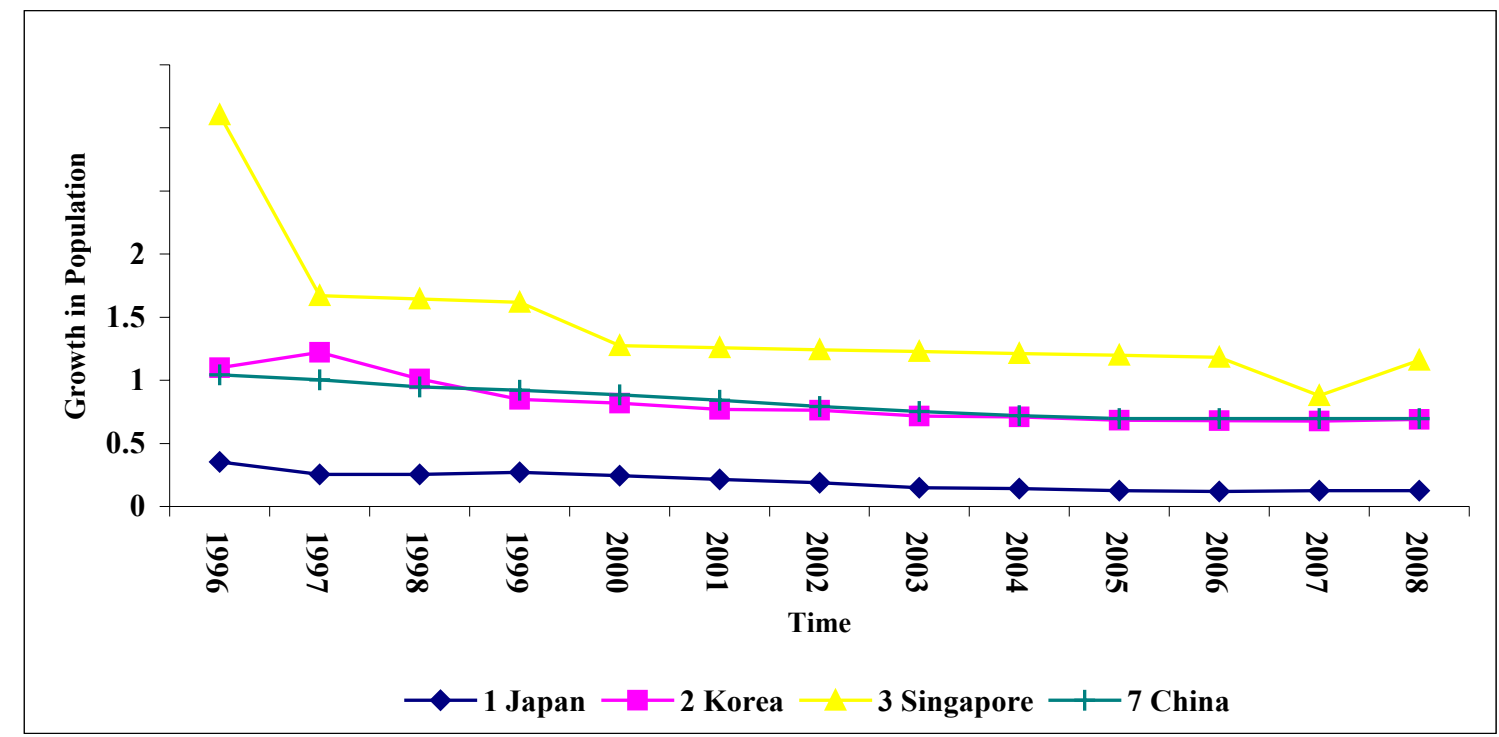

In the baseline capital stocks are the accumulation of investment over time.

Figures 1.1, 1.2 and 1.3 illustrate the growth rates in Real GDP, capital and gross investment. Capital is equal to the capital stocks from the previous period plus gross investment less depreciation of $4 \%$. 1995 to 1997 are taken from historical data and 1998 to 2007 are projections. The decline in real GDP, gross investment and capital stocks in 1997 and 1998 is the result of the Asian crisis, which affected most of the countries examined in this report. Growth in Real GDP of Japan is projected to be low relative to the newly industrialized countries - Singapore and Korea - and significantly lower than China, where very high growth rates are projected.

\section{Figure A.4 Growth in Population}

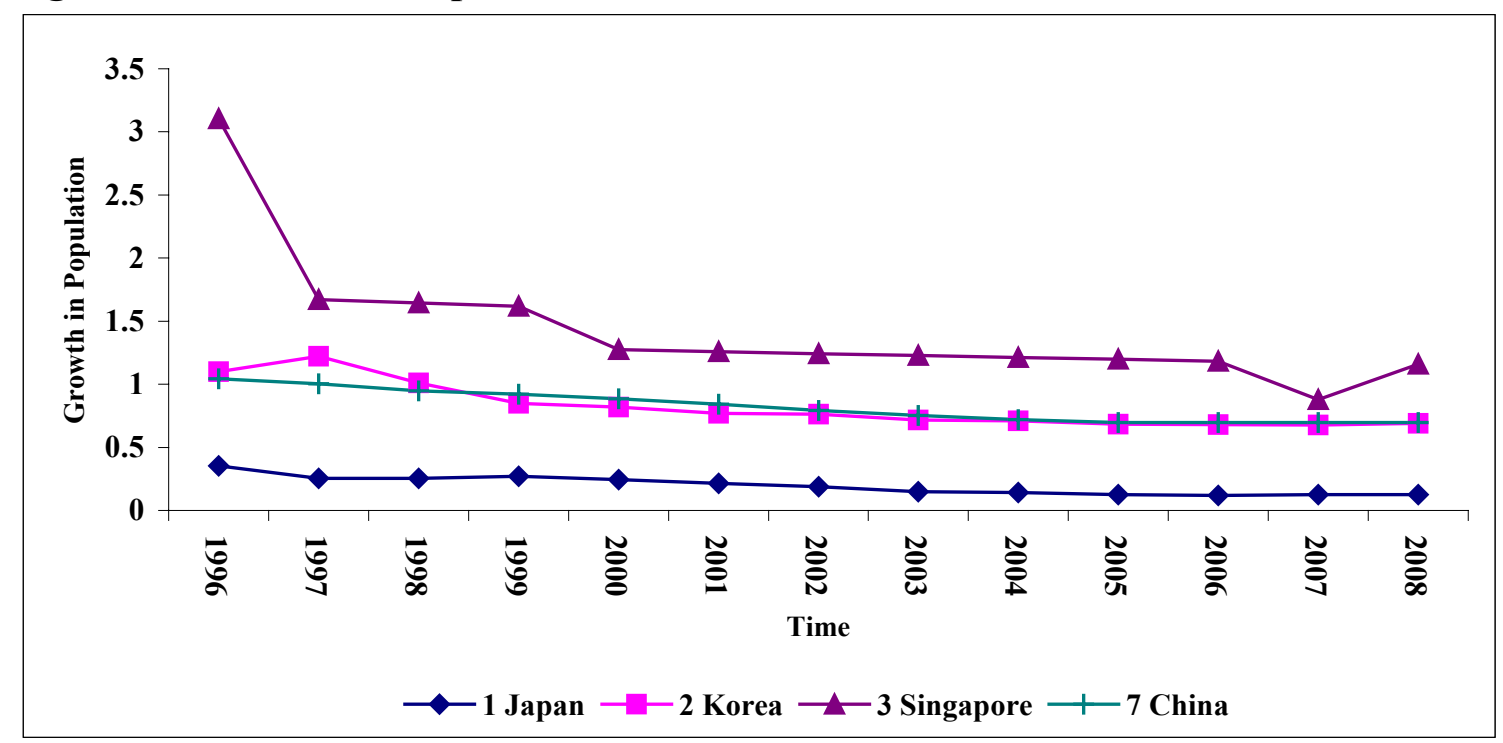


Figure A.5 Growth in Skilled Labor

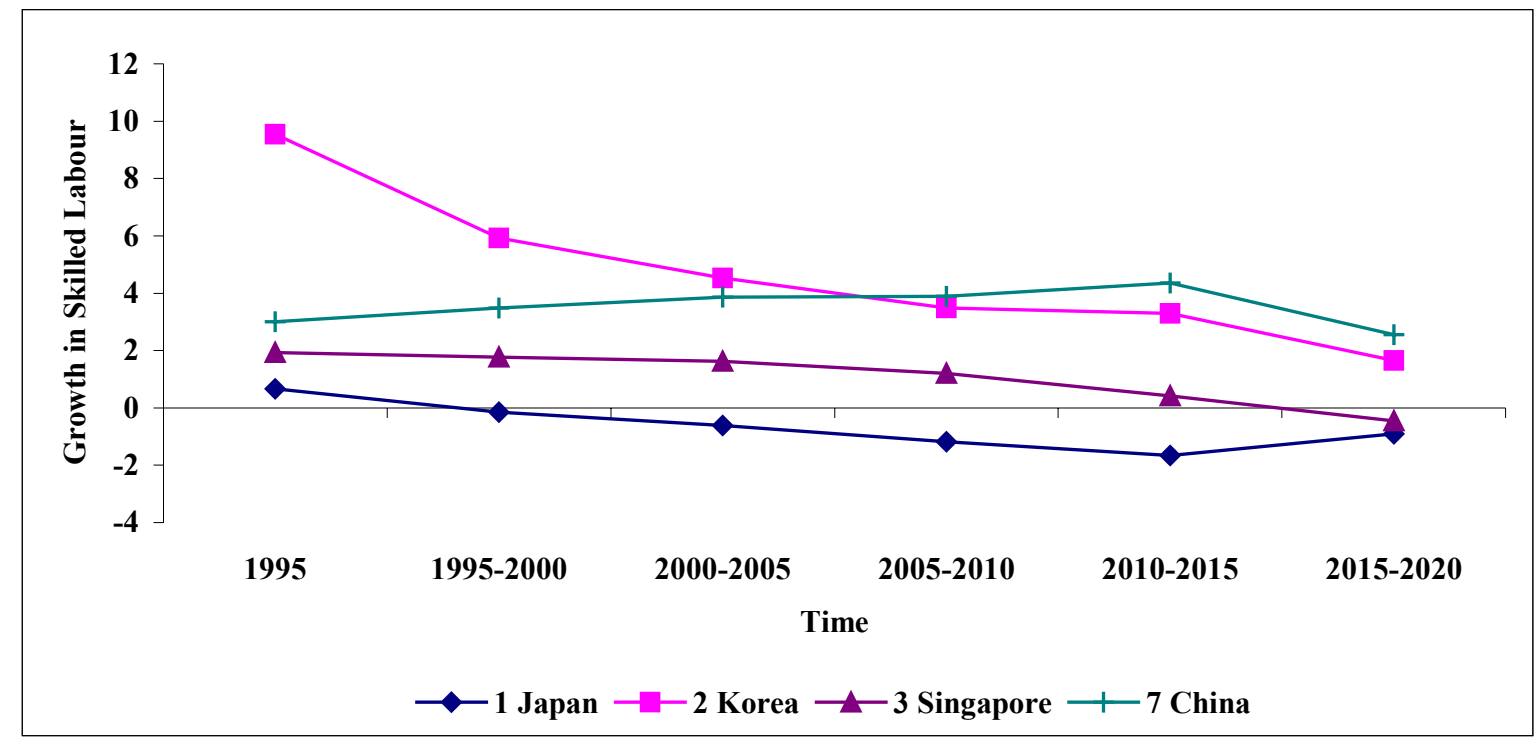

Figure A.6 Growth in Unskilled Labor

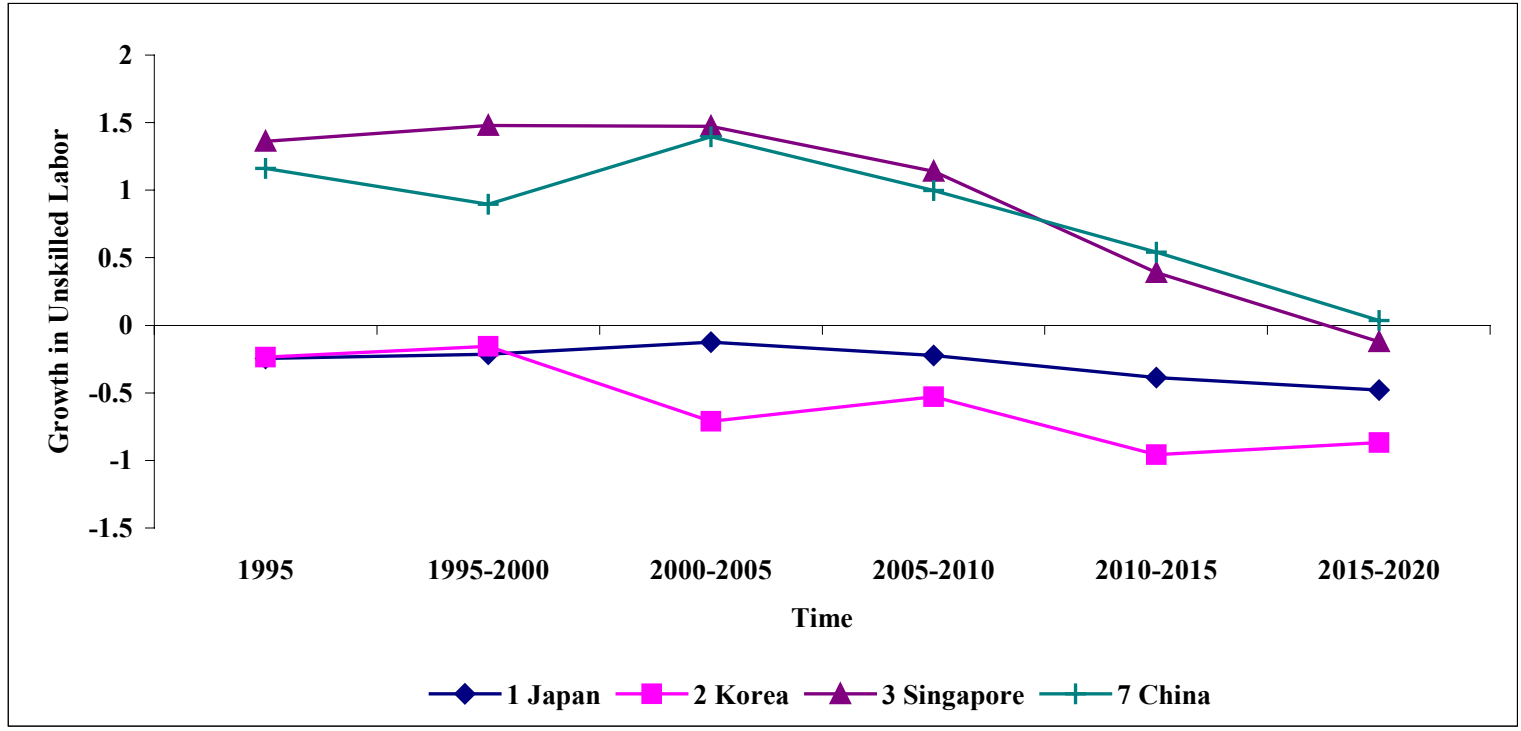

Growth rates of unskilled labor were obtained from taking skilled labor from total labor projected. The growth rate of unskilled and skilled labor decline slowly over time as the population gets older in many of these countries. Although declining over time, skilled labor growth is much stronger than unskilled labor growth due to the emphasis on education and increasing the skill levels of the workforce. In Japan, the population growth rate is very low reflecting the general trend towards very low even negative population growth in the Industrialized countries. In Japan skilled and unskilled labor is also expected to decline.

Not all of these macroeconomic variables are shocked in the baseline scenario. Firstly, the projected changes in population, and skilled and unskilled labor were incorporated into the baseline as shocks to the growth rates of these endowments. Shocks to capital stocks were not incorporated, but 
were determined endogenously as the accumulation of projected investment. Secondly, it is assumed that any changes in real GDP, which were not explained by the changes in endowments, are the result of changes in technology. Forecasts in real GDP are used to calibrate this region-specific change in technology. Finally, forecasts of gross domestic investment over the period are imposed onto the baseline. 